\title{
امتلاكك معلمات العلوم قبل الخدمة بجامعة حفر الباطن للمفاهيم العلمية \\ وأبعاد حب الاستطلاع العلمي (دراسة تقويمية)
}

أ . م . د شرين السيد ابراهيم مخمر

أستاذ مساعد المناهج وطرق التدريس

كلية التربية جامعتي حفر الباطن والمنصورة

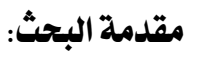

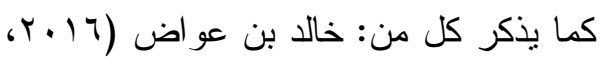

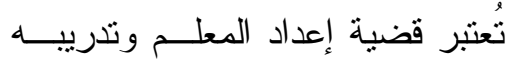

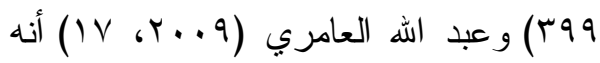
إحدى القضايا التزبوية المهمة؛ حيــث إنـــه بالرغم من الدور الذي تقوم به المؤسـسات يمنل محور التطـــور ومركــز التقــدم فــي

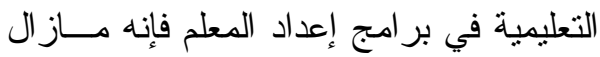
المجتمعات لذلك يجب زيادة الاهتمام بإعداده يحتاج إلى دورات خاصة في القضايا العلمية و الارتقاء بمستو اه الأكاديمي وتحسين أدائـــه

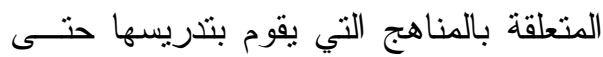

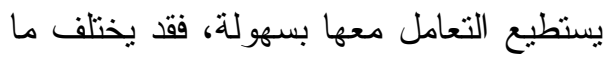
دَرسه المعلم مع ما سيدرّسه.

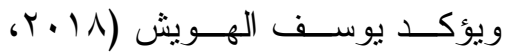
قبل و أثناء الخدمة من خلاء بل بر امج تعليميــة

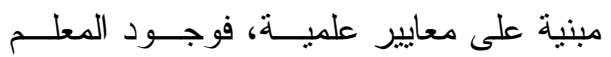

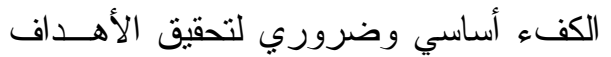

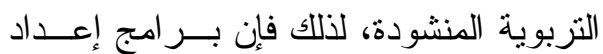

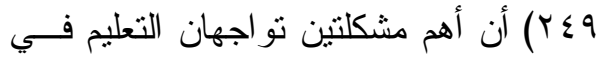

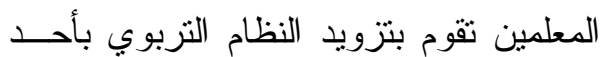

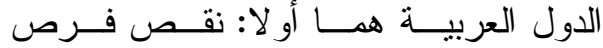
أهم مدخلاته الرئيسة و هو المعلم.

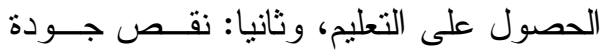

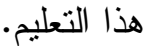

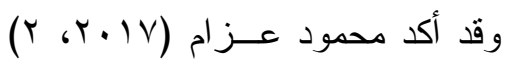
و عليه فإن تقويم بر امج إعداد المعلــــ ضرورة تفرضها منطلبات العصرمن أجـل ألـل على أن هناك حاجة ضرورية لتطوير بر امج تطوير المُخرج التعليمي بما يحقق منطلبــات إعداد المعلم مع التركيـز علــى الاهتمــام

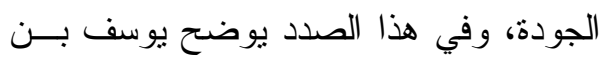

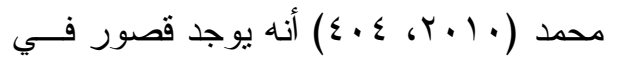

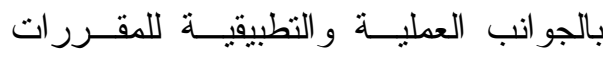
بر امج إعداد المعلم عـن الوفــاء بحاجــات الدراسية في بر امج إعداد المعلم، وبخاصـــة ولمة الطلاب المعلمين في ظل المجتمع المعرفـي لئي التدريب الميداني، وأن تهتم بر امج الإعــداد المنسارع بالتغير و المو اعمة مع المعلومانية، 
خريجو ها بتدريسه في المستقبل مــن مــواد در اسية عامة ومادة العلوم خاصة.

وتعتبر مـــادة العلــوم مــن المــواد

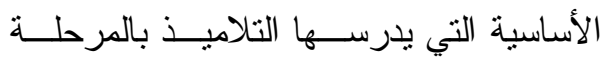
المتوسطة، وتهدف إلى إكــــابهم المفــاهيم العلمية التي تساعدهم على فهم ذاتهم و البيئة من حولهم، وتتمية مهار ات التفكير المختلفة، وتتمية الاتجاهات و القيم العلمية، وهذا يعني ونهي ضرورة أن نتنمل برامج إعداد معلم العلوم

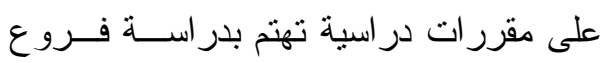
المعارف العلمية المختلفة، ولاسيما العلوم بما

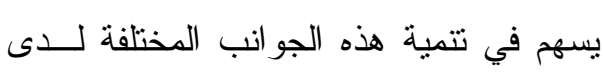
خريجيها.

وتُمنل المفاهيم العلمية البنية الأساسية

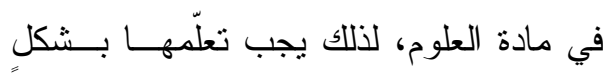

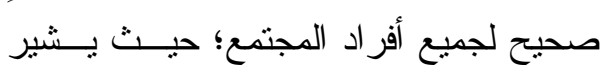

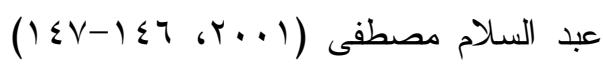
إلى أن التزبية العلمية أكدت على ضـــرورة

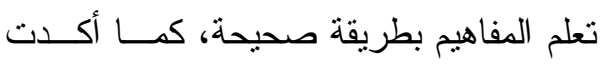
الر ابطة القومية لمعلمي العلوم في الولايــات

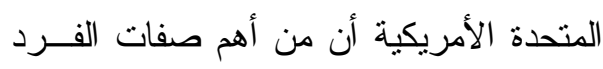
المنقفت علميًا هو الفهم الــصحيح للمفــاهيم العلمية المختلفة بحيث يساعده ذلك في صنع قرار اته وتدبير أمور حياته المختلفة.

ويوضح عايش زيتون ( أن حب الاستطلاع العلمي واحد من مكونات

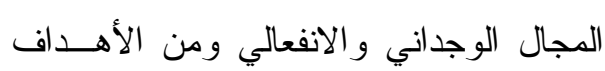

بجو انـــب الـــتعلم المعرفيــــة و المهاريــــة و الوجدانية،

ويكون التوجه نحــو إعــداد معلــم

متخصص ذو نوعية خاصة نتاسب طبيعـة

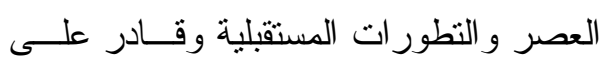
تحقيق متطلبات جودة التعليم.

كما أشتارت بعض الار اســات التـي اهتمت ببر امج إعداد معلم العلوم مثل در ساسة

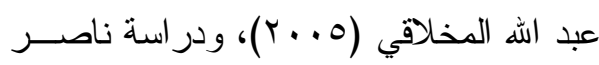

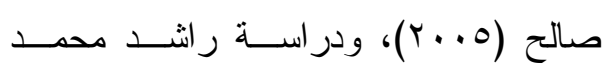
(Y..V)

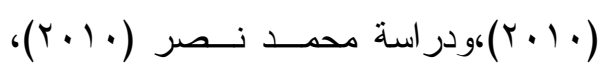
ودر اسة كل مــن إيمـان محمــد، وتهــاني

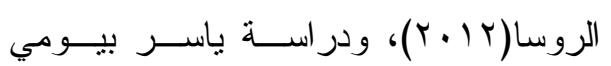

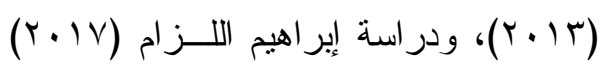
إلى أن درجة ممارسة معلمي العلوم للكفايات

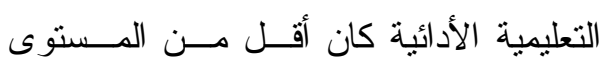

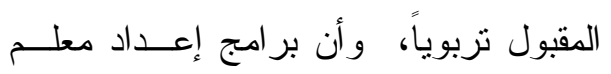
العلوم لا تز اعي الاتجاهات التزبوية الحديثة

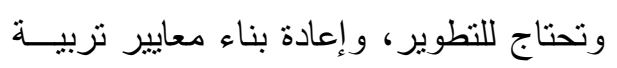

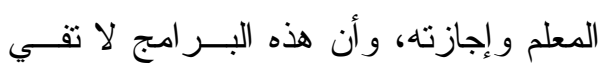
بمعايير الجودة الوطنية للتقــويم و الاعتمــاد

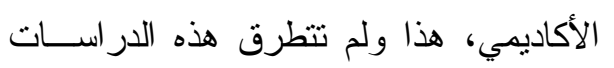

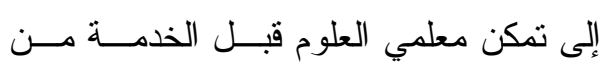
الجو انب الأكاديمية أو الثقافية وما تحتويه من فن فئل معارف ومهار ات مختلفة، ولم تتطرق أيضًا

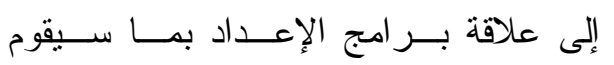


العلمية، و الأمر الثاني: يتمنل في أن تمكـنهم

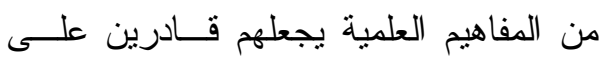
تقديمها بشكل علمي دقيق ومبسط للتلاميذ بما يتلاعم مع طبيعة المرحلة العمرية التي تقدم فيها، أو بشكل دقيق الــتمكن مــن المــادة العلمية، وطريقة تقديمها، وكذلك فإن علــيهم امتلاك أبعاد حب الاستطلاع العلمـي حتـى وطى يسنطيعو ا تتميتها عند متعلمييهم.

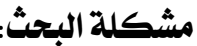
في ضوء ما أثـــارت إليـــه نتــائج وتوصيات البحوث و الدر اسات السابقة التـي في لئي نادت بضرورة الاهتمام بتطــوير برنــامج

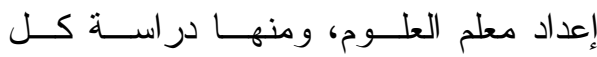

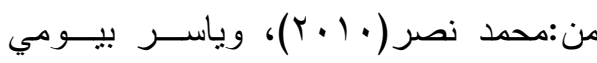

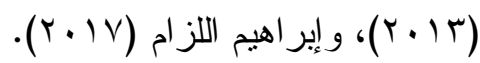

وباستقر اء أهداف الأقــسام العلميـــة

بكلية التربية جامعة حفر الباطن، وجد أن من

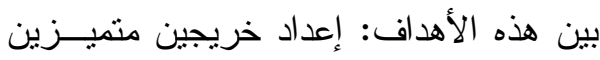
ومؤهلين في مدارس التعليم قــادرين علــى توصيل المفاهيم العلمية و إكـسـاب طلابهـــ مهار ات البحث العلمـي، وتحسـسين جـودة البحث العلمي، وخدمة المجتمع و المؤسسات الحكومية في مجــالات العـــوم المختلفــة،

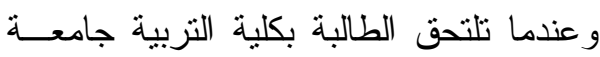

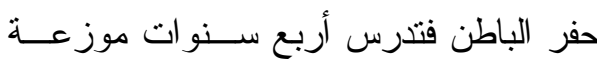

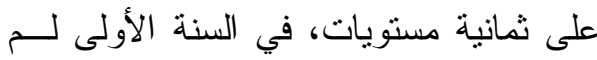
تتخصص الطالبــة و إنمـــا تــدرس خــلال
المرغوبة التي تسعى التربية إلى تحقيقها في

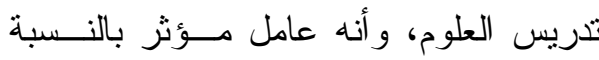

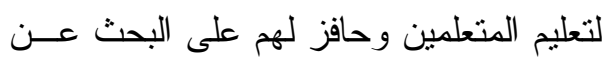

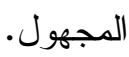
يتضح مما سبق أن مساعدة المتعلمين على اكتثاف المعرفة العلمية بصورة وظيفية وتتمية المفاهيم العلمية لديهم ينعكس علـى تحصليهم الدراسي، و الذي يرتبط بمـــؤثرات أخرى منها حب الاسنطلاع العلمي وهذا من أهم الأهداف التي تسعى التربية العلمية إلـى

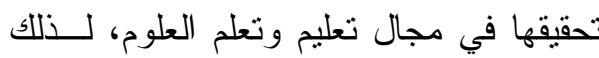
يجب مر اعاة ميول المتعلمـين و اهتمامــاتهر نحو العلوم، حيث إن حب العلوم هو هـدف هيد أساسي من أهم أهداف تدريس العلوم. ولذللك ينبغي التأكيد على جعل المتعلم

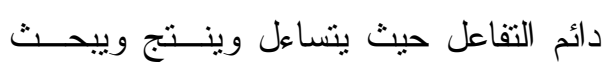
ويتقصنّى ويكتشف بدلاً من در اسة المعلومات وحفظها ثم استرجاعها عند الحاجـــة إليهــا، ونسا.

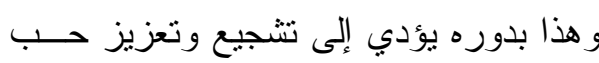

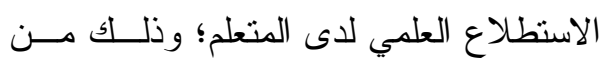
أجل تكوين قاعدة من المتعلمــين المتفــوقين وتوجيههم بطرق علمية نحو الإبداع. وفي ضوء ما تقدم فإن معلمي العلوم

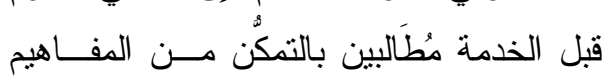

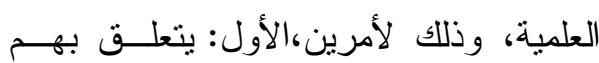

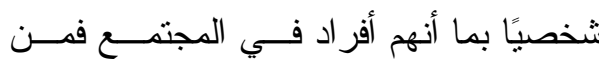

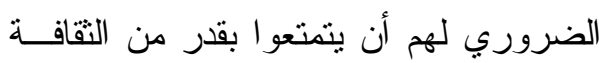


الباحثة بالتدريس لعينة البحث فقد لاحظت أن

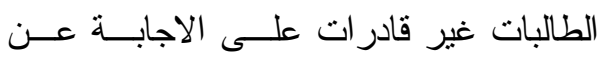

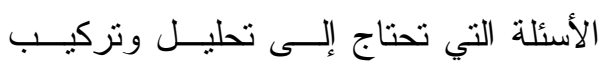

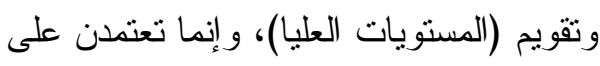

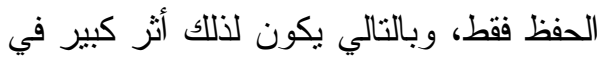

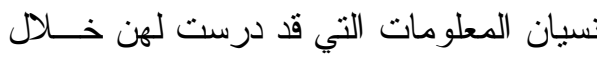

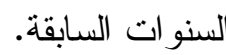

بناءً على ما تقدم تتمتل مشكلة البحث

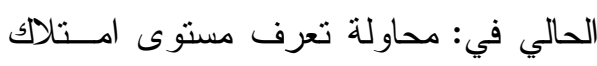

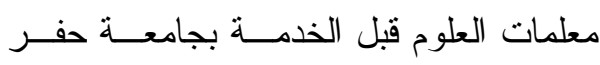

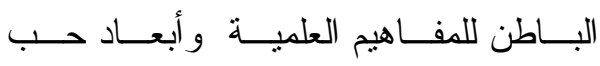

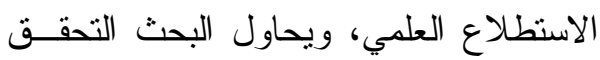

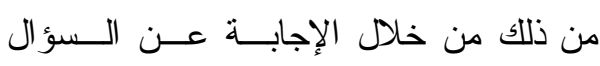
الرئيس التالي: ما مستوى امتلاك معلمــات

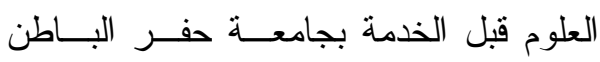
للمفاهيم العلمية وأبعــاد حــب الاســنطلاع العلمي؟ تساؤلات البحثـ تفرع عن الــسؤال الــــئيس الأسئلة الفرعية التالية: ما المفاهيم العلمية المتـضمنة فـي مناهج العلوم للمرحلة المتوســـة بالمملكـــة العربية السعودية؟ ما مستوى امتلاك معلمات العلوم قبل الخدمة جامعة حفر البــاطن مــن المفــاهيم العلمية المتضمنة في مناهج العلوم للمرحلـــة المتوسطة؟
المـــــتويين الأول و الثتـــاني المقــــررات التالية:(ب) ساعات معتمــدة مقــرر فيزيــــاء عامة، و (ع) ساعات معتمدة مقـرر كيميــاء

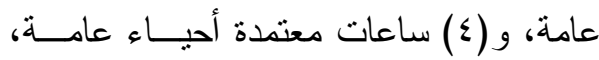
وبعد اجتياز هـــا للمـستوبين الأول و الثـاني تلتحق بالمستوى الثالث في السنة الثانية حيث تتخصص في هذا المستوى سو اء فيزيــاء أم كيمياء أم أحياء على حسب معــلها الــذي لــي حصلت عليه خلا المستويين الأول والثاني (كلية التزبية، جامعة حفر الباطن). هذا وبالإضافة لمتابعة الباحثة لبعض

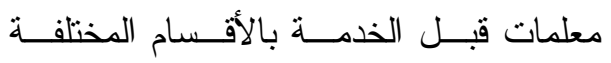
(الأحياء، و الكيمياء، و الفيزياء) في التـدريب الميداني بمدارس المرحلة المتوسطة نتيجـــة ولئة العجز الثنديد فــي عــدد مــدارس التعلــيم الثانوي، وحيث أن كتاب العلوم يتضمن كافة

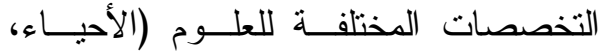

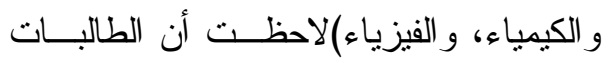

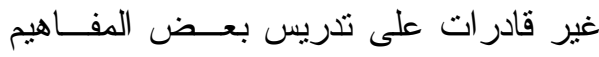

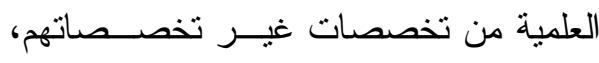
وكذلك عدم تمكـن بعـــهن مــن شــرح وتوضيح بعض المفاهيم العلمية المتـضمنة في مناهج العلوم للمرحلة المتوسطة، بجانب

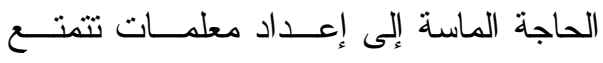
بالقدرة على التفكير في ظـــل عـــالم متغيـــر

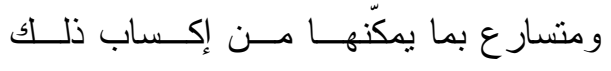
لمتعلميها، بالإضافة إلى ذلك فمن خلال عمل بل الك 
المقارنة بين مستوى امتلاك معلمات

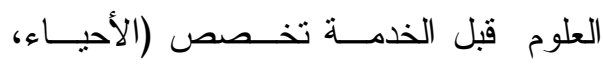
الكيمياء، الفيزياء) لأبعاد حب الاستطلاع. أهمية البحثـ في ضوء نتائج البحث الحــالي يمكن له أن يسهم فيما يلي:

أنه يأتي استجابة للأبحاث و الدر اسات التي نادت بضرورة ثقويم برنــامج إعـــداد

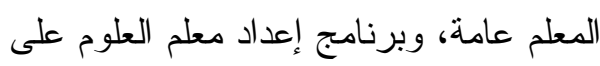
وجه الخصوص. أنه يمس جانبًا مهمًا في عملية إعداد

$$
\text { معلم العلوم قبل الخدمة. }
$$

أنه يقدم تشخيصاً لمـستوى تمكـن معلمات العلوم قبل الخدمة (عينة البحث) من

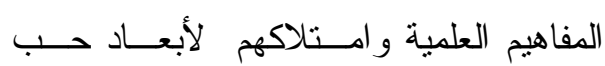
الاستطلاع العلمي.

يمكن أن يكون البحث مؤشرًا لتطوير

برنامج إعداد معلم العلـــوم بكليـــة التربيــة

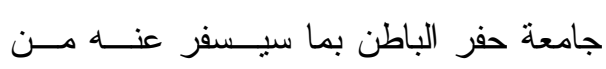
نتائج.

حدود البحث ــ اقتصر البحث الحــالي علـى

الحدود التالية:

بناء اختبار للمفاهيم العلمية المتضمنة

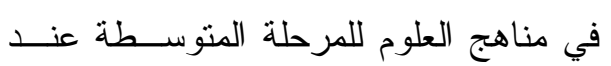
مستويات بلوم المعرفية الستة. بناء مقياس حب الاستطلاع العلمــي أبعاد في ضوء ما أثنارت إلبه الدر اسات
هل يوجد فرق بين منوسط درجــات

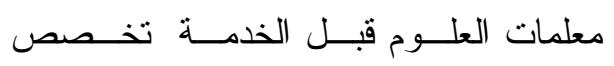

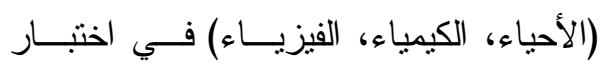
المفاهيم العلمية المنضمنة في مناهج العلــوم للمرحلة المتوسطة؟

ما مستوى امتلاك معلمات العلوم قبل

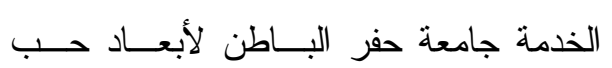
الاستطلاع العلمي؟

هل يوجد فرق بين متوسط درجــات

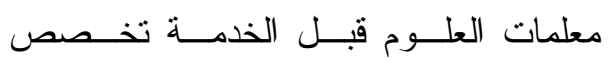
(الأحياء، الكيمياء، الفيزياء) في مقياس حب مب الاستطلاع العلمي؟

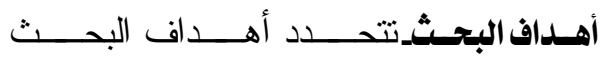
فيما يلي: تحديد المفاهيم العلمية المتضمنة فـي مناهج العلوم للمرحلة المتوســـة بالمملكــة العربية السعودية. تعرف مستوى معلمات العلوم قبـلـل الخدمة من المفاهيم العلمية المتــضمنة فــي مناهج العلوم للمرحلة المتوسطة. المقارنة بين مستوى معلمات العلــوم قبل الخدمة تخصص (الأحيــاء، الكيميــاء، الفيزياء) في المفاهيم العلمية. تعرف مستوى معلمات العلوم قبــلـ الخدمة في مقياس أبعاد حب الاسنطلاع. 
الكيمياء، الفيزياء) بكلية التربية جامعة حفــر

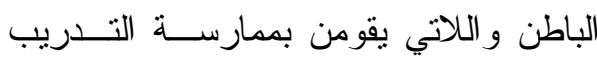

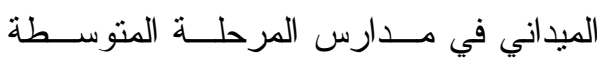
و المرحلة الثانوية بمحافظة حفر الباطن.

المفاهيم العلمية Scientific Concepts: تُعرّت إجر ائيًا أنها: كلمة أو اســـم أو

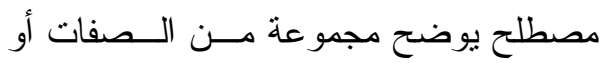

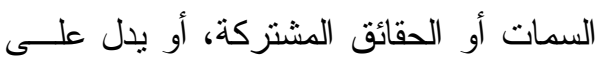

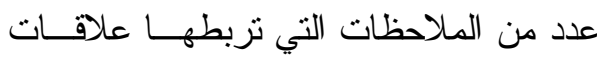

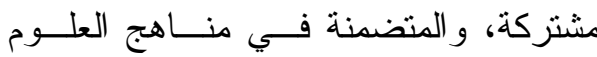

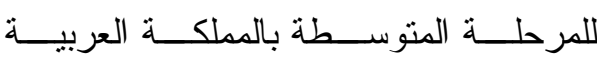

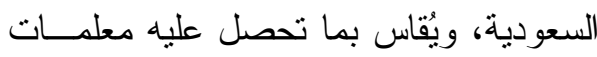

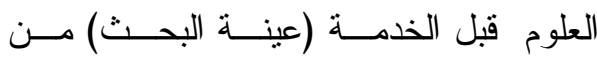
درجات في الاختبار المُعد لذلك.

Scientific

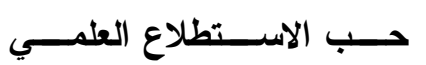
:curiosity

يُعرف إجر ائيًا أنه قدرة معلمات العلوم

قبل الخدمة (عينة البحث) علـى الاســتجابة للمثير ات المتتوعة على شكل مواقف حقيقية

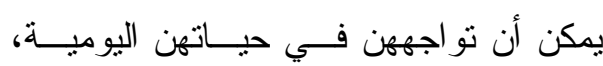

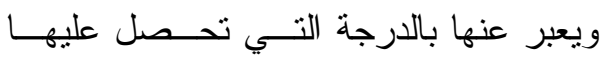
المعلمة من خلال المقياس المعـــ خصيـــــاً لذلك ويتضمن أربعة أبعاد هـيـي: الاهتمــام

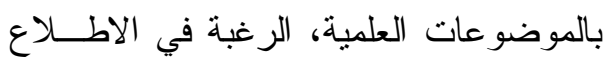

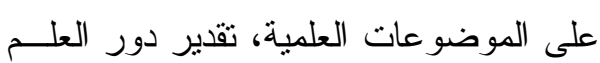

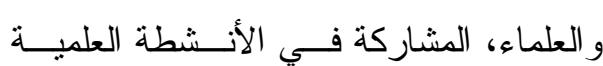
(المنهجية-اللامنهجية).
السابقة وهي: الاهتمام بالموضوعات العلمية،

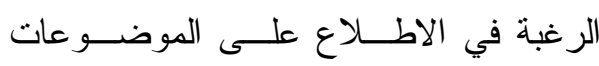
العلمية، تقدير دور العلم و العلماء، المشاركة في الأنشطة العلمية (المنهجية- اللامنهجية). ، مجموعة من طلاب المسستويات ^) بالأقسام العلمية بكلية التربية جامعة حفر طلئ

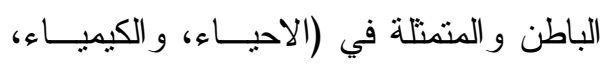

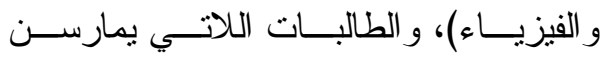

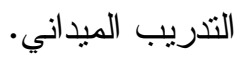

تطبيق أدو ات البحـــث فـــي الفـــل

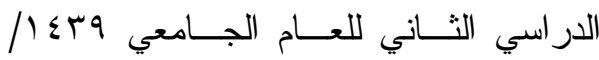
$\cdot(5+19 / r \cdot 11) 01 \leq \varepsilon$. نتائج البحث وتوصياته مرتبطة بزمن تطبيقه و عينته وليس لها صفة التعميم المطلق.

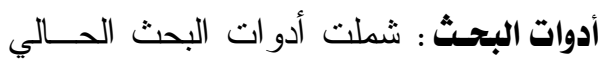
على ما يلي : البئ : اختبار المفاهيم العلميــة المتـضمنة بمناهج العلوم للمرحلة المتوسطة بالمملكــة العربية السعودية.(من إعداد الباحثة) مقياس حب الاستطلاع العلمي. (من إعداد إد لئه الباحثة) مصطلحات البحث:

Pre-service معلمات العلوم قبل الخدمة :science Teacher يقصد بهـن فــي البحـــث الحــالي: مجموعة من طالبات المـستويات الأخيــرة

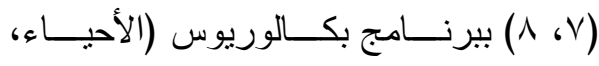


معارف عن مادة تخصصه و علاقتها بالمو اد

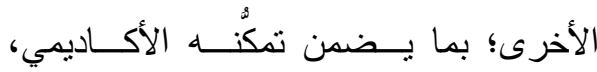
و الإعداد التزبوي ويتم ذلك بتزويده بـــالعلوم

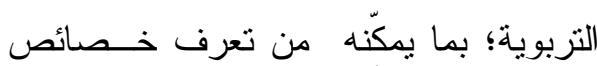

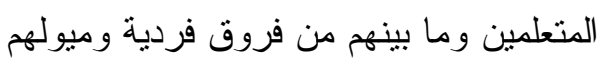

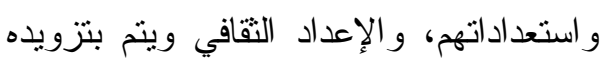

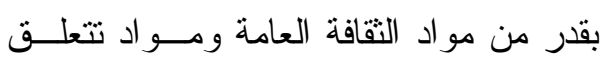

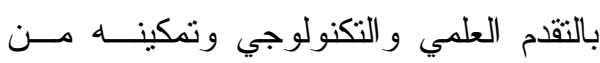

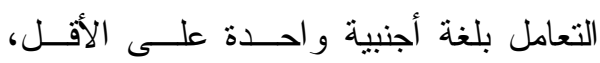
و الإعداد المهني (التزبية العملية) وهي الحقل

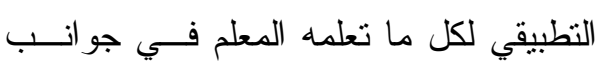
الإعداد الأخرى. - إن.

وتوضح كل من ابتسام ناصر وعبير

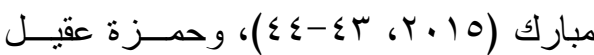

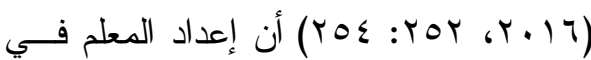
بر امج الإعداد في جامعات المملكة العربيــة السعودية يقتصر على ثلاثة جو انب؛ وهـي لإسي الإعداد: الأكاديمي، و المهني، و الثقافي.

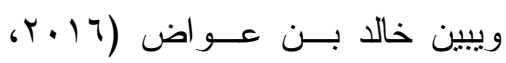

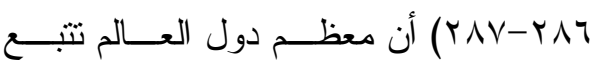
نظاميين أساسيين في إعداد المعلمين وهما: النظام التكاملي: وهو النظام المتبــع

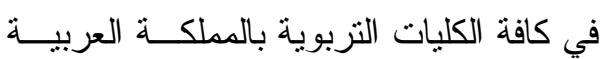

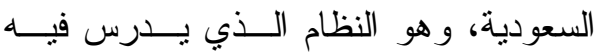
الطالب المقرر ات التخصــصية و المقــررات التزبوية و الثقافية معاً خلال فترة إعداده التي ولي

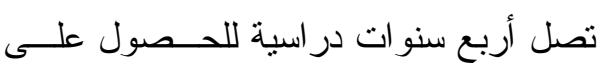

\section{الإطار النظري والدراسات السابقة: المحور الأول: برامج إعداد معلم العلوم}

تُعد قضية إعداد المعلم بصفة عامـــة

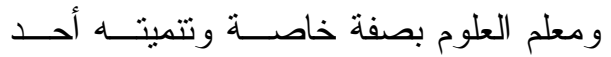
القضايا التربوية المهمة؛ حيث يُعد المعلم هو العامل الأساسي في تطوير أي عمل نربوي لئريه في المجتمع وهو عنصر مهم فــي إحــداث

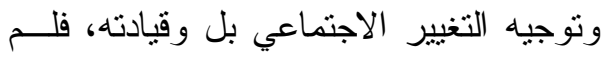
يعد مجرد ملقن لطلابه و إنما هو المـسؤول

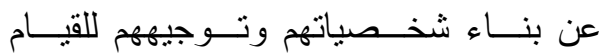

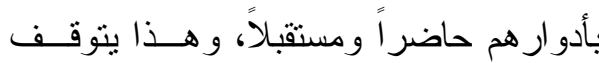

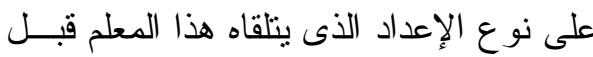
الخدمة، و على مستوى الاهتمام بتطوير نفسه وقدرته أثناء الخدمة.

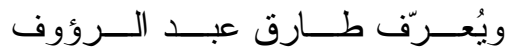
برامج إعداد المعلـــم أنهـ ( AV ، . . N) بر امج مخططة ومنظــــة وفــق النظريــات التربوية النفسية الني تقوم بهـــا مؤسـسـات تربوية متخصصة لتزويد الطلاب بالخبرات العلمية و المهنية و الثقافية بهدف نزويد مترويد المستقبل بالكفايات التعليمية التي تمكنهم من ون النمو في المهنة وزيادة إنتاجيتهم العلمية. ويوضح كل من محسن عطية وعبــد

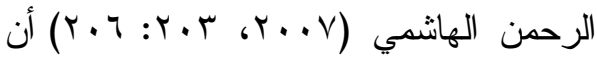
إعداد المعلم في بر امج الإعداد يتم في أربعة جو انب وهي: الإعداد الأكـاديمي (الإعـــداد التخصصي) ويتم ذلك بتزويده بما يلزمه من الإن الإدي 
ومؤهلين في مدارس التعليم قــادرين علــى في

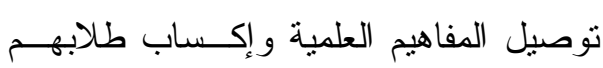

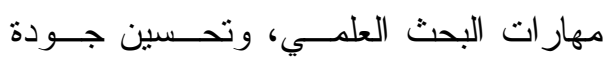
البحث العلمي، وخدمة المجتمع و المؤسسات الحكومية في مجالات العلوم المختلفة، وذلك وخلك

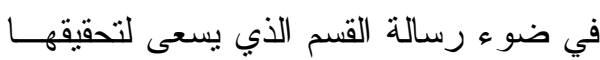

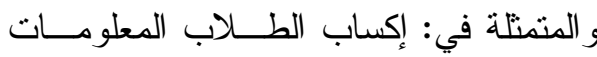

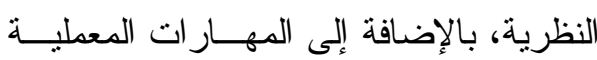

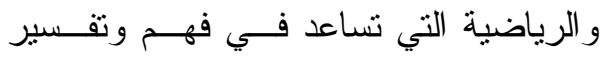

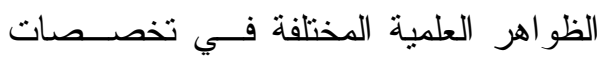
الفيزياء و الكيمياء و الأحياء، وتحسين جـــودة

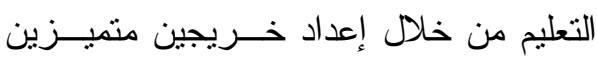
ومؤهلين للعمل في مدارس التعلــيم العــام، مخدئ. وخدمة المجتمع و المؤسسات الحكومية مــن ملـن خلال تقديم المحاضر ات العامة والاسنشار ات العلمية وورش العمل (كلية التربية، جامعــة حفر الباطن). ولقد خضعت بــر امج إعــداد معلــم

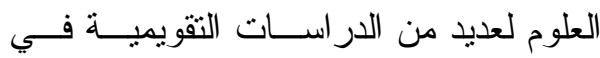

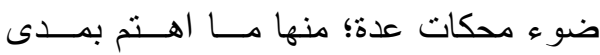

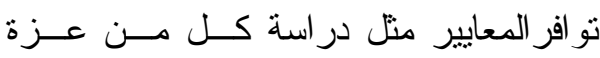

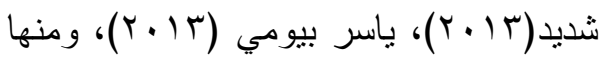

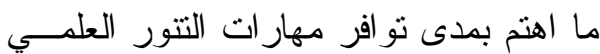

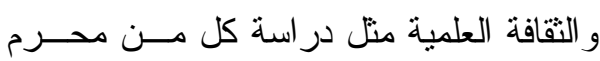

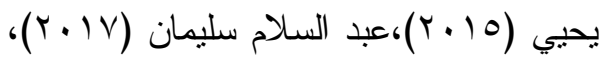

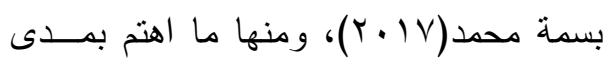

درجة البكالوريوس، ويتم فيه إعداد الطالــب نربوياً و أكاديمياً و مهنياً.

النظام التتابعي: وهو النظـــام الــذي

يدرس فيه الطالب المقرر ات التخصصية فقط وهي

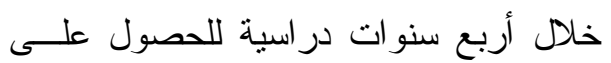
درجة البكالوريوس في تخصص مــا، ثــم يدرس الطالب المقررات التربوية لمدة ســنة

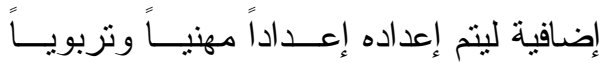
ليحصل بعدها على الدبلوم العام في التربية،

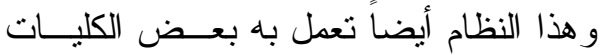

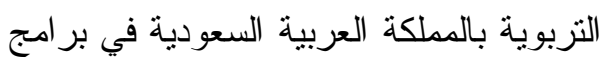

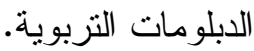
ويتم إعداد معلمات العلــوم بكليـــة التربية جامعة حفر الباطن من خلال نظــام الإعداد التكاملي، و الذي يتم فيه الموازنة بين

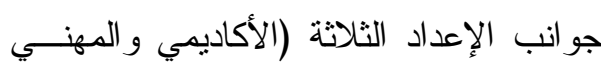
و الثقافي) في أربع ســنوات موزعــة علــى إنى

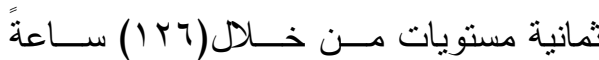

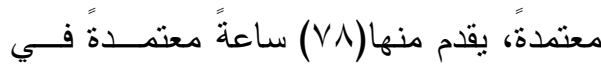

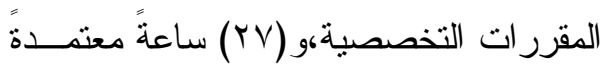
في المقررات التربوية، و(T) الماعةً معتمدةً

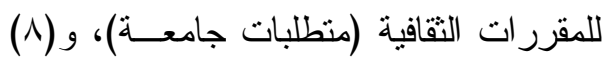
ساعات معتمــدةً للتــــريب الميــداني(كليــــة التزبية، جامعة حفر الباطن). ويَهدف قسم العلوم الأساســـية بكليــة التزبية جامعة جفر الباطن إلى: تحسين جودة

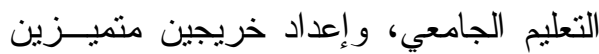


من الملاحظات المنظمة، ويُعـرّت بطـــــ

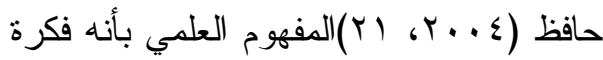
عامة أو مصطلح يتفق عليه الأفراد نتيجــة

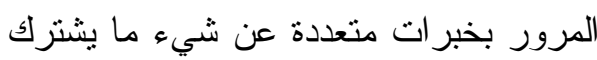
في خصائص محددة يتفق فيها كل أفر اد هذا

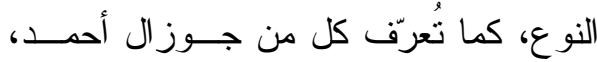

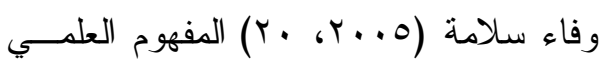
بأنه تصور عقلي مجرد يعطي اسماً أو لفظاً

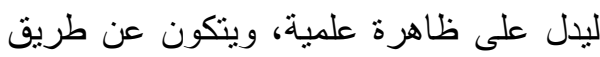
تجميع الحقـائق و الخــصائص المـشنتركة لعناصر هذه الظاهرة، وأيضا أوضحت فادية

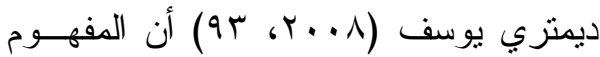
في أبسط تعريف له ما يتكون لدى كل فــرد من معنى وفهم يرتبط بكلمات أو عبار ات أو لأ

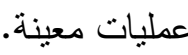

من خلال ما سبق يتضح أن المفهوم العلمي عبارة عن تصور عقلي أو حدث أو لون ظاهرة تحدده مجموعــة مسن الخـصائص ويمكن التعبير عن المفهوم باستخدام مصطلح أو رمز أو كلمة.

ولتعلم المفاهيم العلمية أهمية كبيــرة

لجميع المتعلمين على اختلاف مر احل تعلمهم

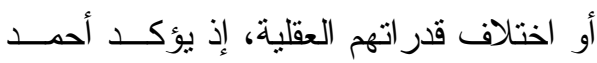

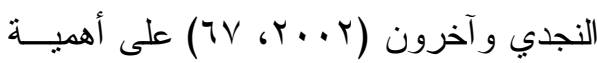

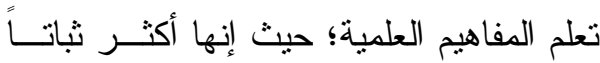

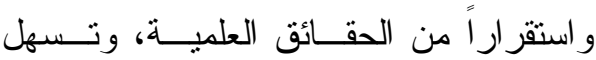
در اسة البيئة، وضرورية لتكــوين المبــادئ ولئ
تو افر منطلبات الاقتصاد المعرفي منل دراسة

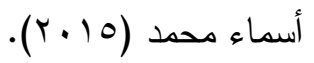

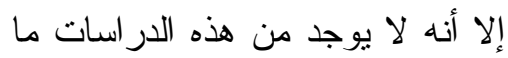

تتاول برنامج إعداد معلم العلــوم بجامعــة فئة

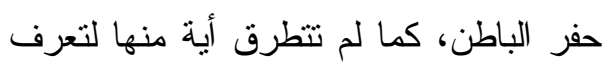
مستوى تمكن معلمات العلوم من الجوانــب

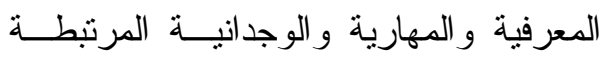
بالمو اد الدر اسية عامة ومادة العلوم خاصة. المحور الثاني: المفاهيم العلمية. إن التطورات الحالية التي أدت إلــى

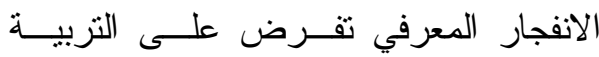

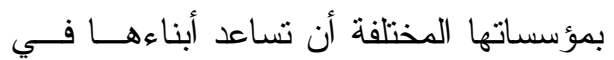
مو اجهة هذه النطور ات، وأيـــاً الاهتمــام بأساسيات العلم التي تعتبر المنطلق الأساسي لفهم العالم من حولنا، ومن هنا نأتي أهميــة تدريس المفاهيم العلمية للتلاميذ في المدارس. وتتعد المفاهيم العلمية من أهم نـــواتج

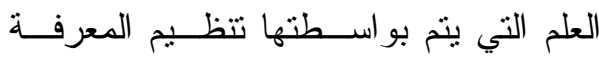

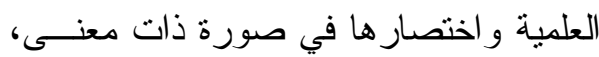

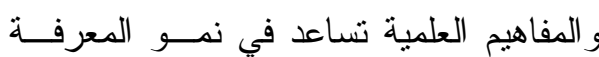
العلمية وتطوير ها، كما أنها تمتل معنى العلم

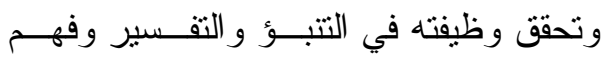
الظو اهر الطبيعية.

ويُعرّت أحمـــــ النجــدي و آخـــرون

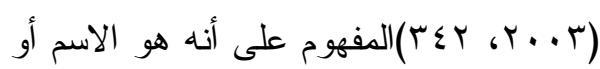
المصطلح الذي يعطى لمجموعة من الصفات

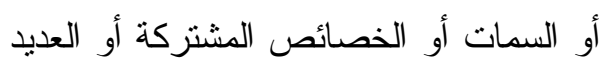


(2005) Otto تذريبياً - قبل الخدمة- قائم على الاستقصاء لمعلمي العلوم بالحلقة الابتدائية، وذو علاقــــة

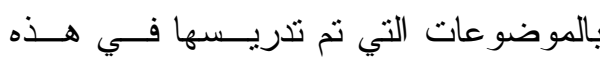

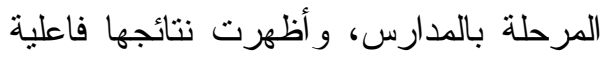
البرنامج في تتمية المعرفة العلمية وفي تتمية

كفاءاتهم تجاه تـــــيس العلــوم، دراســــة مasien قياس مخرجات التعلم على المــدى القـصبر و المدى الطويل لبرنامج تدريبي فــي أثتــــاء

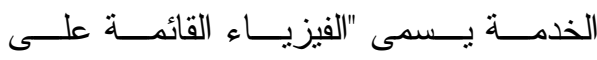
الاستقصاء" ويهدف إلى تعميق المعرفة فـي

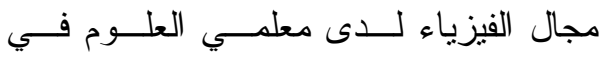

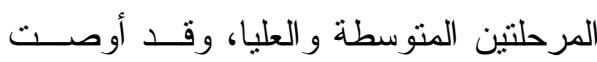
الدراسة بضرورة إعداد بر امج تدريبية فـي ولي لئي

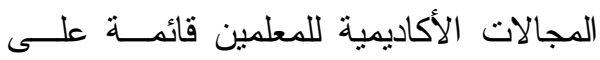
الاستقصاء وتهدف إلى توسيع معرفتهم حول المحتوى الذى يقومون بتدريـسـه، ودر اســـة

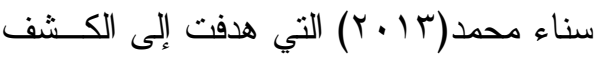

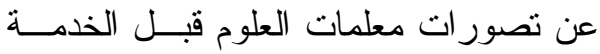

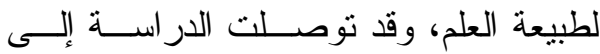
وجود خلــط بــين التـصورة ات الـصديحة و الخاطئة لاى عينة الدر اسة في تــصور اتهن

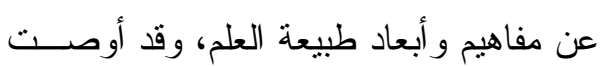
الدر اسة بالاعتماد في برامج إعداد معلمـي لعي

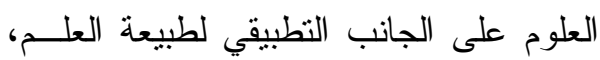
و إقامة الدورات التذريبية لتدريب المعلمــين
و القو اعد و القوانين و النظريات العلمية، ولها

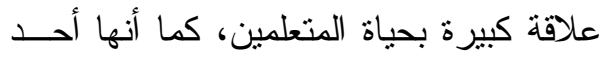

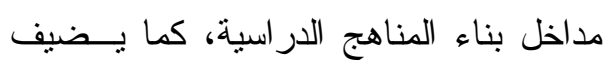

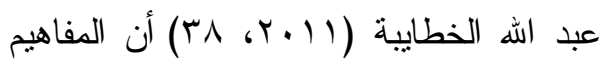
العلمية تعتبر من أهم جوانب تعلـــم العلــوم

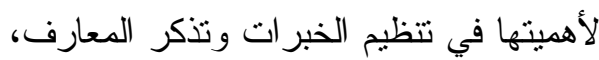
و اختصار ها في صورة ذات معنى ومتابعــة

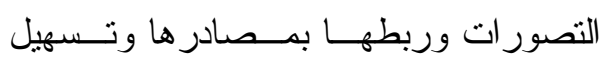
الحصول عليها.

لذلك يجب على معلمي العلــوم قبـــل الخدمة التمكن من المفاهيم العلميـــة بـشكلٍ يجعل منهم مو اطنين منقفين علميًّا قـادرين

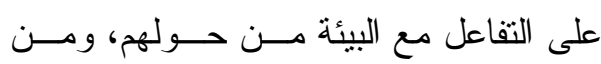
ناحية أخرى فإن تمكنهم من هـــهـ المفــاهيم يجعلهم يكونون صورة ذهنية صحيحة عـن هذه المفاهيم في بنيتهم المعرفية بما يساعدهم على تقديمها بـصورة صــحيحة ومناســبة

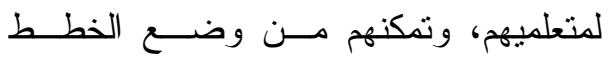

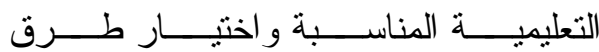

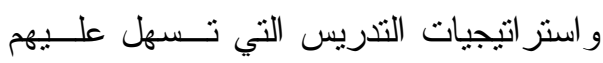
تقديمها، و أيضا يستطيعون اختيار وتــصميم الوسائل و الأنشطة التعليمية المناســبة التـي ولئي تساعدهم في تقديم هـــهـ المفــاهيم بــصورة سليمة وو اضحة. وقد أجريت بعض الدراسات لتعرف وم: مستوى امتلاك معلمي العلوم قبل الخدمة من Luera, بعض جو انب التعلم، ومنها در اسة لعنة 
وفيما يخص التمكن مــن المفــاهيم

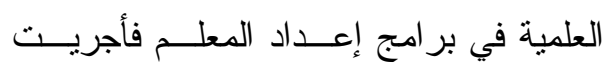
بعض الدراسات، ومنها در اسة كل من ماجدة

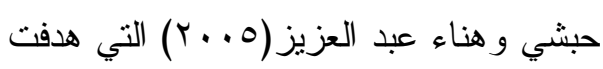

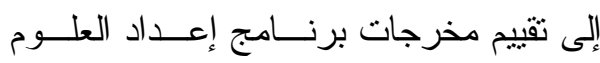
البيولوجية بكلية التربية جامعة الإســكندرية

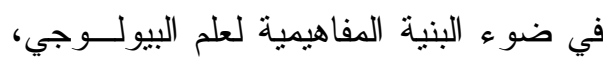
وكثفت نتائجها عن وجود انخفاض في تمكن معلمي البيولوجي قبل الخدمة من المفــاهيم البيولوجية و الجيولوجية، ودر اسة ليلى يحيي لئي

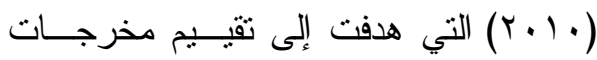

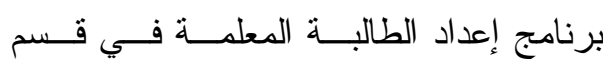

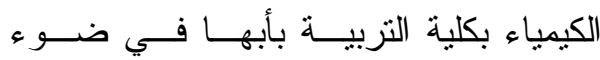

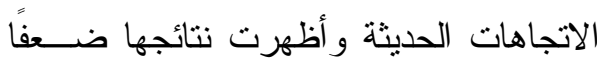
ملحوظًا لدى طالبات قسم الكيمياء في الإلمام

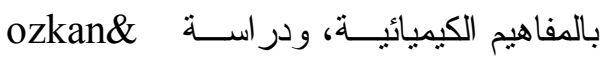
Akcay معلمي العلوم قبل الخدمة من المفاهيم العلمية

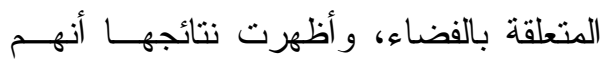
يعانون من الفهم الخطأ لهذه المفاهيم.

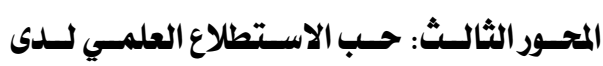

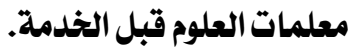

يتميز الإنسان بسمة حب الاسنطلاع

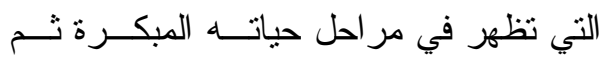

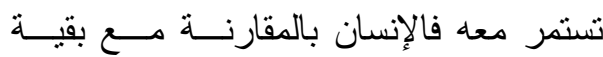
الكائنات الحية دائم البحث و التعرف على كل بلى بلعان شيء في بيئته، فالعصر الحالي الذى نعيــشه
على تضمين طبيعة العلـــم أثثـــاء التــدريس وتوعيتهم بأهميتها، ودر اسة عمر سيد خليل

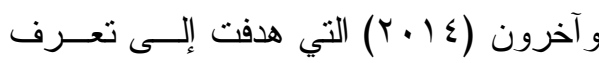

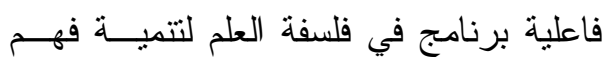

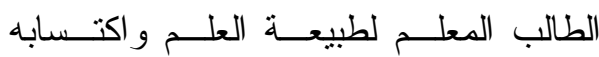
أخلاقياته، وقد أوصت الدر اسة بعدة نوصيات أهمها الاهنمام بضرورة تضمين فلسفة العلم كمقرر در اسي ضمن برنامج إعداد معلمـي الهي

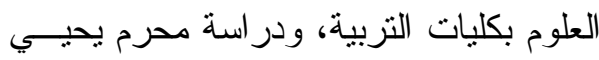

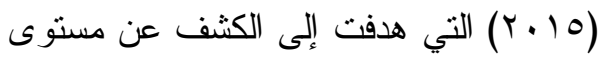
مهار ات التتور العلمي لدى معلمي العلوم قبل و أثناء الخدمة، وتأثثير نظام الإعداد التكاملي

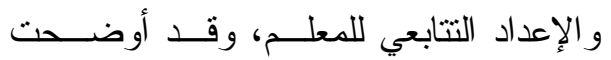

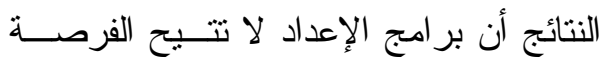

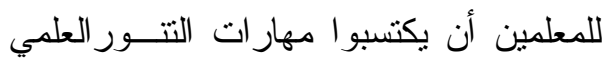

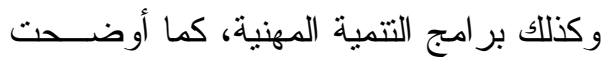
الار اسة وجود قصور في مسنوى مهــار ات النتور العلمي سواء للمعلمين قبل أو أثتــاء

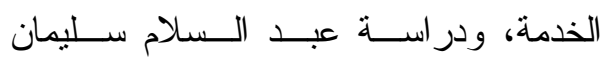

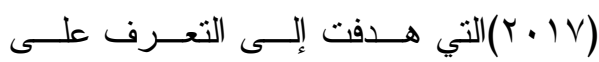
مستوى الثقافة العلمية لدى معلمي الكيميــاء و الأحياء قبل الخدمة الملتحقين ببرنامج إعداد معلم العلوم بكلية التربية بجامعة عمران في

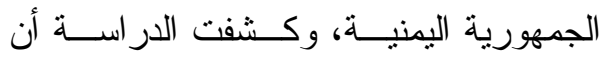

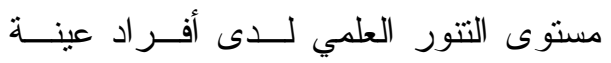
الدر اسة بشكل عام كان متدنيا؛ حيث كانـــت

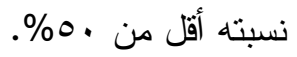


بالظواهر و الأحداث المحيطة بهــا، ومـــى مشاركتها بالأنشطة العلمية المتتوعة، ويعرفه

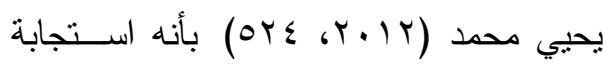
استكثافية تفحصيه في شكل استفسار يبديـــ التلميذ للحصول على المعرفة العلمية تعـالج الرغبة في الحصول على المعرفـــة العلميـــة و التعلم، وذللك على شكل موقف حقيقي يمكن أن يو اجهه التلميذ في الحياة اليومية. ويؤدي حب الاسنطلاع دوراً مههــاً

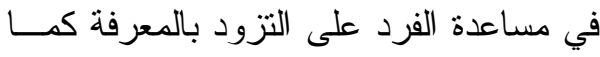
أنه محرك أساسي مــن محركــات العقــل فئل البشري نحو التساؤل والاستفسار كما يؤدي دوراً كبيراً في التحصيل الدراسي للمتعلمين فهنالك علاقة إيجابية بينه وبــين التحـصيل الدر اسي، فــالمتعلمين الــذين لــديهم حـبـ استطلاع مرتقع سوف يسألون أسئلة أكثــر ويشاركون بشكل أكثر نشاطاً من المتعلمــين المنخفضين في حب الاسنطلاع، كمـــا أنـــه أكثر الدوافع ضرورة لرفع دافعية المتعلمين

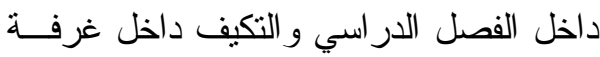

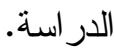
لذا تؤدى المؤســسة التعليميــة دوراً كبير اً في تتمية المرونة العقليــة للمتعلمـين حتى تمكنهم من التعامل مع تغير ات العصر ، ويمكن المساهمة في تحقيق هذا الهدف عـنـ

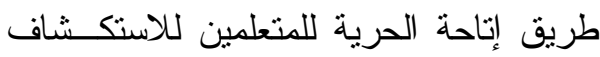

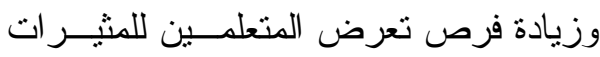

يفرض علينا العمــل علــى زيــــادة توعيــة المتعلمين بالأحداث البيئية ومثثير اتها و العمل

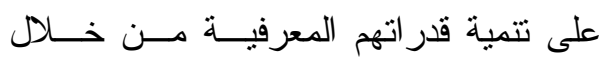
تشجعيهم على حب الاستطلاع و الاستكثناف.

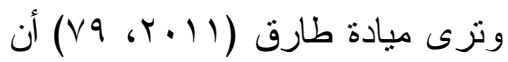
الاتجاهات تساعد الطلاب على تحديد مو اقف و اضحة ومحددة لموضوع أو مادة در اســية

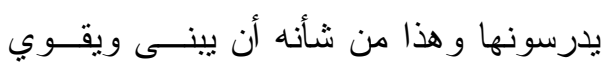

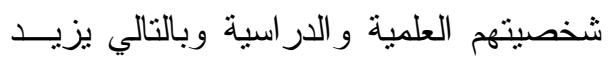

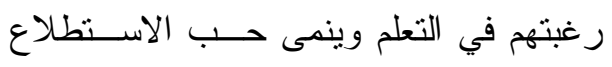
لديهم.

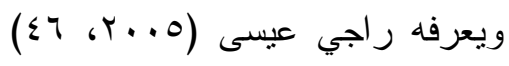
بأنه هو المثابرة و الاستطلاع بإصر ار للبحث

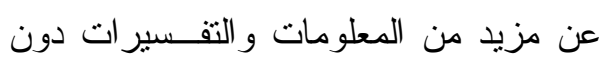

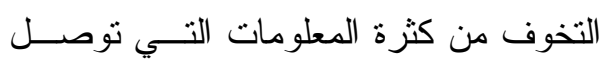
إليها المتعلم، وهي نظرة متفائلة إلى المستقبل واعتقاد أن من الأفضل أن نتحسن المعلومات عن طريق عقل الباحث المستقصي، في حين

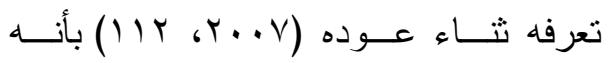

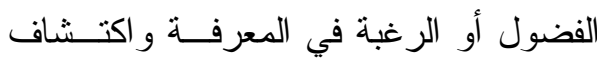
وفهم البيئة والاتجذاب نحو المثيرات الجديدة، بينما يعرفه كل من ثائر غباري، وخالد أبــو

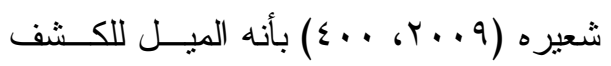

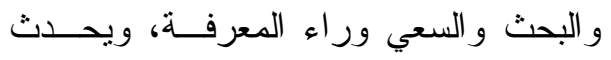

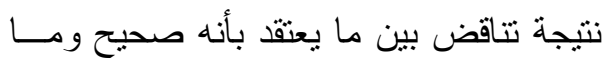

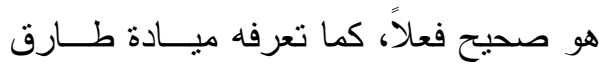

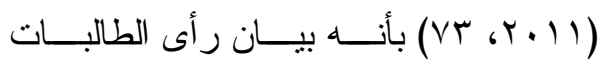




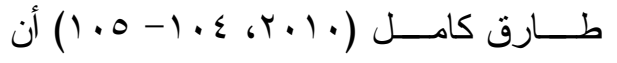
المتعلم يتصف بحب الاستطلاع عندما ينظر إلى المستقبل نظرة متفائلة، يبحث عن أكتــر

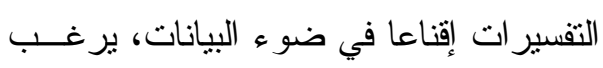

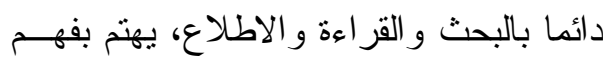

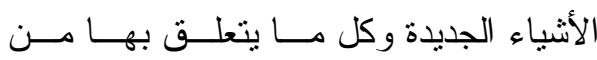
استفسار ات ونقد ومناقثنة.

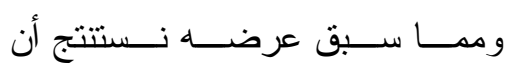
المتعلمين الذين يتصفون بحــب الاســنطلاع

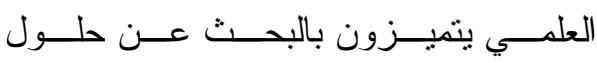

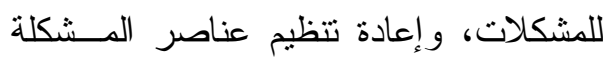

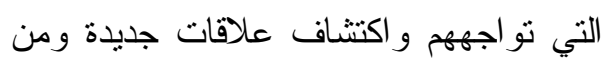
ثم إيجاد حلول جديدة لهذه المشكلة، و الانفتاح

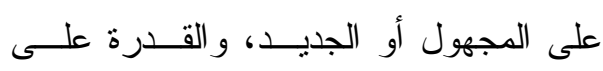
التعبير عن الذات.

ويتضمن حب الاســنطلاع العلمـي

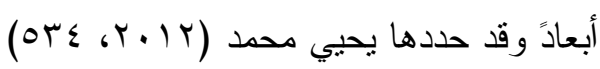

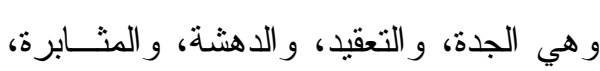

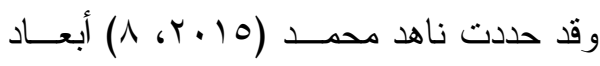
حب الاستطلاع العلمي في حب الموضو عات

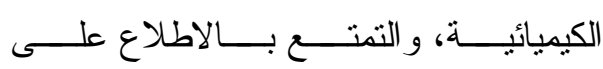
الموضوعات الكيميائية، تقدير العلم و العلماء،

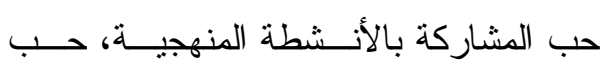
المشاركة بالأنشطة اللامنهجية، بينما حددت بالات

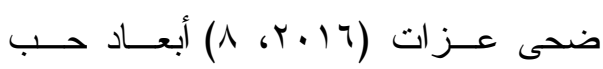

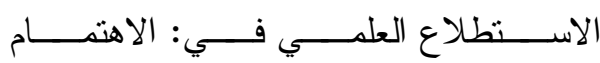
بالموضو عات المرنبطة بالنباتات، الرغبة في
التي تثير فيهم حب الاستطلاع العلمي، حيث

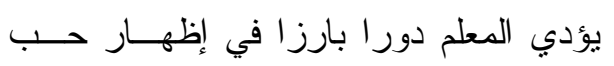

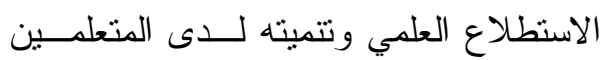
وذلك باستخدام طرق تدريسية و اسنر اتيجيات تثير حب الاستطلاع العلمي لديهم ، وتــــوفير المختبرات العلمية و التجارب التي يخوضـــــها المتعلم بنفسه، و الاهتمام بالزيار ات الميدانيــة والأماكن العلمية لما لها من دور إيجابي في

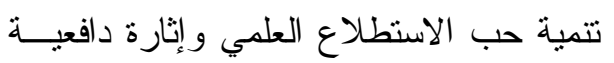
المتعلمين نحو البحث و التتقيب. و هناك سمات يتصف بها المتعلهــون الذين ينوفر لايهم حب الاستطلاع العلمي فقد

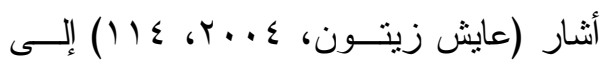
بعض السمات التي يتميز بها المتعلم المحب

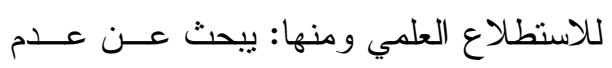

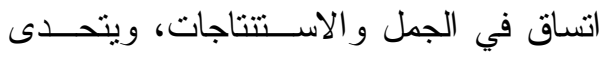
صدق الجمل أو الجمل غير المدعمة علمياً،

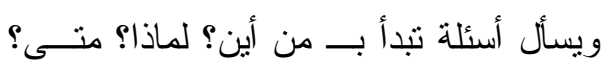

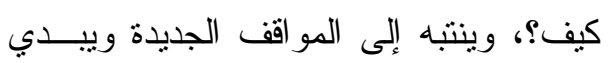

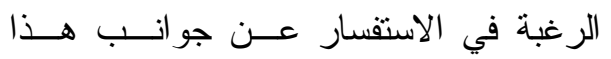

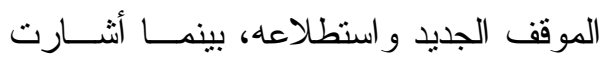

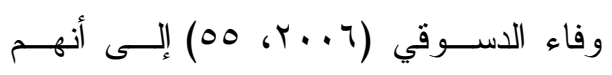
يتصفو ا بما يلي: غالبا يتعلمون أكثر مما هو

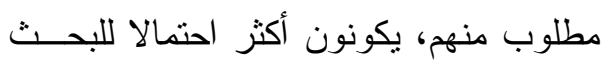

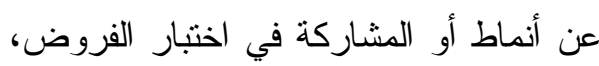
بذل محاولة إيجابية في تعلم ومسايرة الأفكار

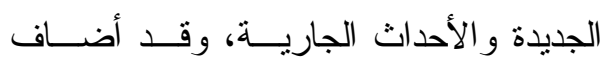


التعاوني لاى تلاميذ المرحلة الابتدائية فـي

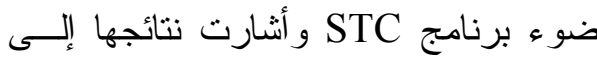

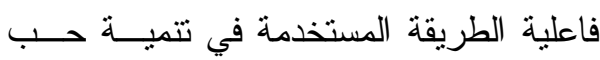
الاستطلاع العلمي لاى عينة البحث، در اســـة

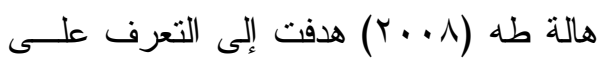
فعالية برنامج قائم على الوسائط المتعددة في الفي العلوم على تتمية حب الاستطلاع و الابتكارية لاى تلاميذ الصف الأول المنوسط بالمملكــة العربية السعودية وأثنارت نتائجها إلى فعالية البرنامج المستخدم في تتمية حب الاستطلاع لدى عينة البحث، ودر اسة هدى بنت محمــد

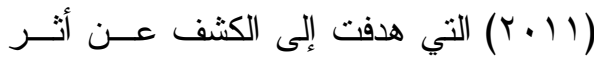
استخدام الوسائط المتعددة في تدريس العلوم

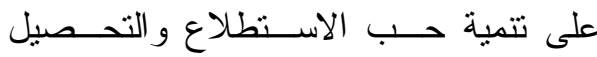
الدر اسي لدى تلميذات الصف الر ابع الابتدائي

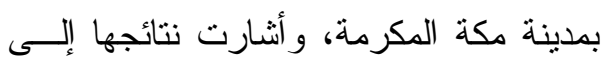
فاعلية الوسائط المتعددة فــي تتميــة حـبـ الاسنطلاع لاى عينة البحث، ودر اسة ميادة

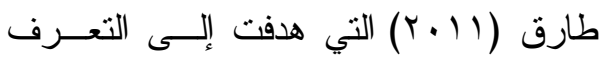

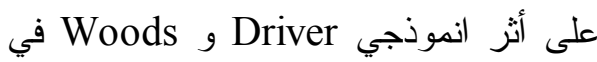
اكتساب مفاهيم الصحة المدرسية و اســتبقائها وتتمية حب الاستطلاع العلمي لاى طالبــات

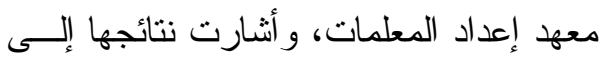
فاعلية انمــوذجي Driver و Woods فـي تتمية حب الاستطلاع العلىــي لــدى عينــة

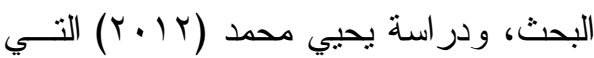
هدفت إلى فاعلية دورة التعلم الخماسية فــي
الاطــــلاع علــــى الموضـــــوعات العلميــــة،

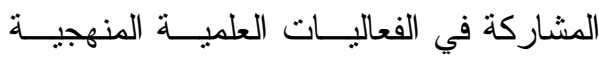

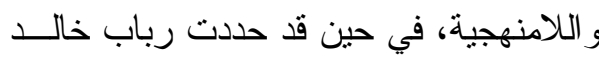

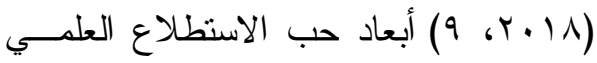
في: الجدة، التعقيد، التتاقض، الغموض. وفي ضوء ما تقدم قد حددت أبعـاد حب الاسنطلاع العلمي في البحث الحالي في

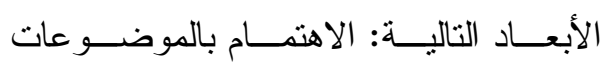

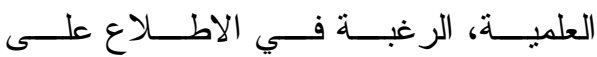

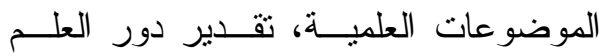

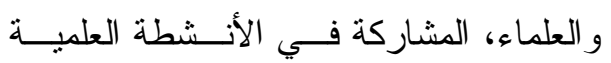
(المنهجية- اللامنهجية).

هذا وقد تتاولت بعـض الدراســات فاعلية استر اتيجيات تدريسية مختلفة في نتمية

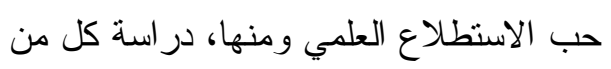
(2006) Verling,etal در اسة أثر برنامج في العلاقات المتضمنة في

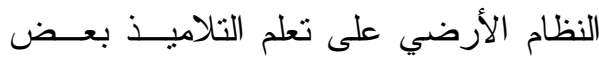

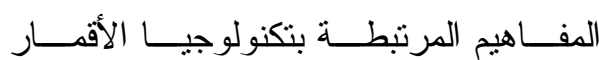
الصناعية وتتمية حب الاســنطلاع و التقــة بالنفس ليكونوا علماء ومفكرين في المستقبل

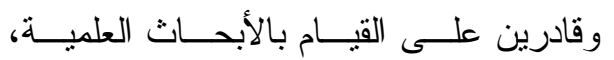

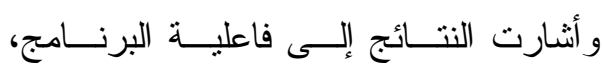

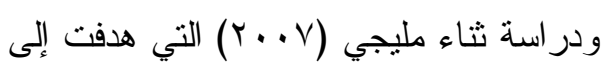
فاعلية التــريس بالأنـشطة الاستق صـائية

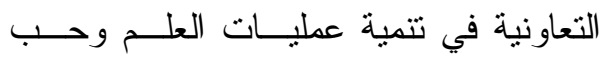

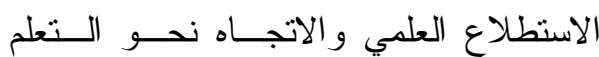


ودراســـة Kesner Baruch, et al (2016) التي هدفت إلى استنكـشاف حــبـ الاستطلاع و الاتجاه نحو البيئة لأطفال ما قبل

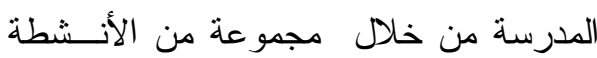

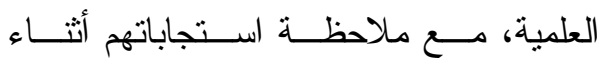
الاندماج في هذه الأنشطة، وقد تم ملاحظــــة حب الاستطلاع والاتجاه نحو العلــوم مــن فـن خلا مؤشرين هما: الاستجابة اللفظية و التي

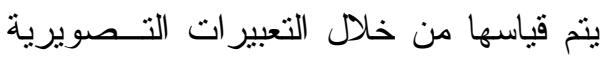

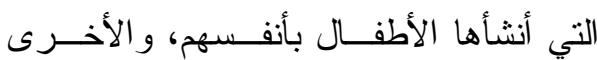
الاستجابات السلوكية (هي تعبير ات حسسية)

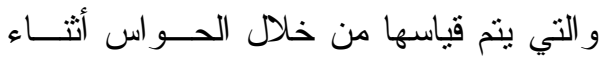

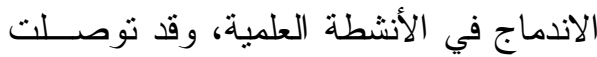
الدراسة إلى أن استجابات الأطفال للتعبير ات التهات

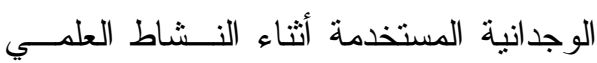

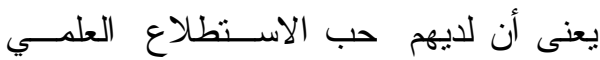

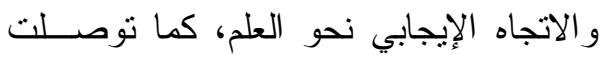

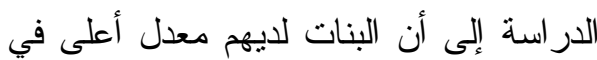
استجاباتهم العلمية وحب الاستطلاع العلىـي لـي

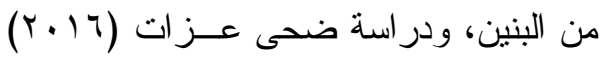
التي هدفت إلى تعرف أثز نموذج درايفر في ودري

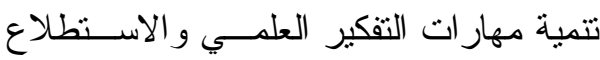

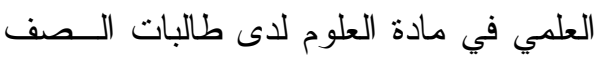
التاسع الأساسي، وأثنارت نتائجها إلى فاعلية نموذج درايفر في تتمية حـب الاســنطلاع العلمي لاى عينة البحث .
تتمية المفاهيم العلمية وعمليات العلــم حـب الاستطلاع العلمي لدى تلاميذ الصف الثامن

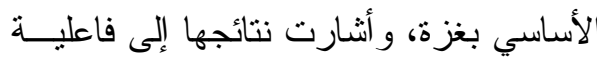

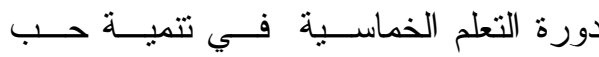

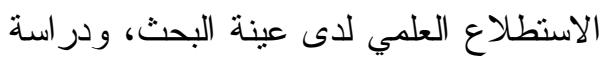

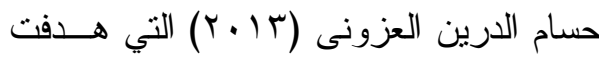
إلى محاولة تقصي تتمية كل مــن المفــاهيم العلمية وبعض مهار ات الاستقصاء العلىـي وحب الاستطلاع العلمي لدى تلاميذ الــصف

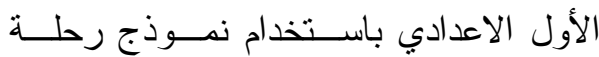

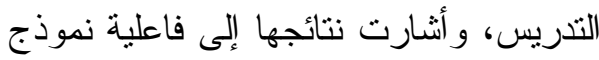
رحلة التدريس في تتمية حـب الاســنطلاع

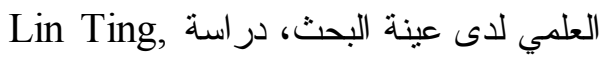
Moi Siew استكثاف أثز تدريس بعض الأنشطة العلمية خار ج الصف الدر اسي بحيث تكون في بيئــة

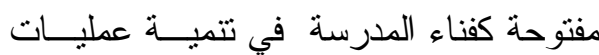

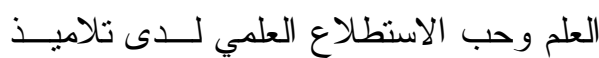
الصف الخامس، وقد توصلت الدراسة إلـى الـى

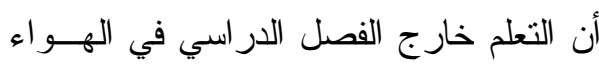

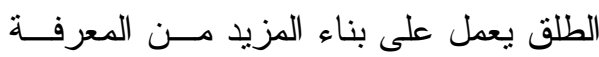
أكثر من داخل الصف مما بسهم في تتميــة

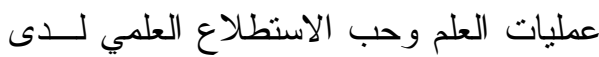

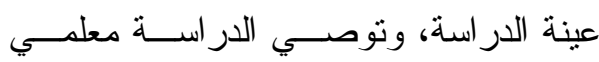
العلوم بالتدريس خارج الصف من أجل تتمية

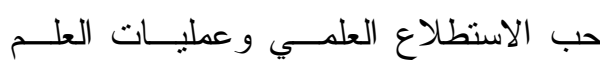
لتلاميذهم من خلا الأنشطة المثيرة للتفكير، وعلمات 
الخدمة تخصص (الأحيـــاء، الكيميــاء،

الفيزياء) في اختبار المفاهيم العلمية.

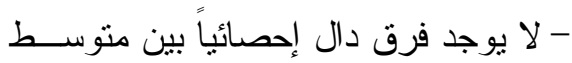

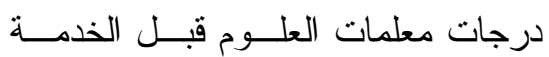

(عينة البحث) و المتوســـ الاعنبــاري

المقدر بـــــ من الدرجــة الكليــة

لمقياس حب الاستطلاع العلمي.

- لا يوجـــد فــرق دال إحـــصـيائياً بـــين

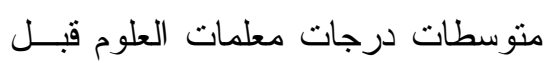

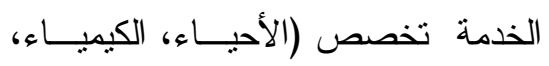

الفيزياء) في مقياس حــب الاســنطلاع

العلمي.

المنهج والإجر اءات:

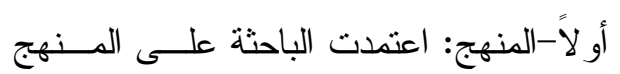

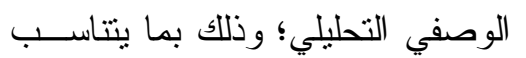

$$
\text { مع طبيعة البحث وأهدافه. }
$$

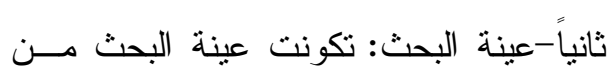

عينتين كما هو موضح في جدول(1):
وباستقر اء هذه الدر اسات يتـ ضضح أن

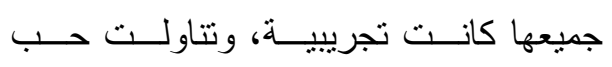

الاستطلاع العلمي كمتغير تابع، كمــــا أنهــا

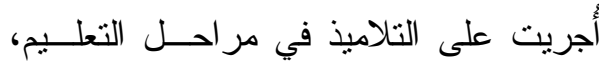

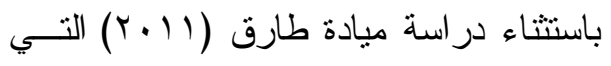

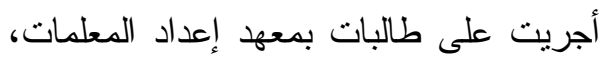

كما لم تتطرق هذه الدر اسات إلى قياس أبعاد

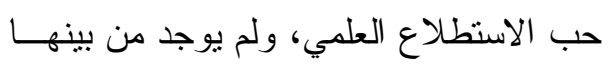

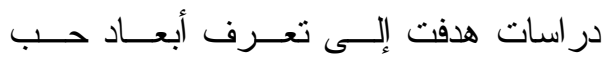

الاستطلاع العلمي لدى المعلمين قبل الخدمة.

فـروض البحث: تمثلت فروض البحــث فــي

الآتي:

- لا يوجد فرق دال إحصائياً بين منوســـ

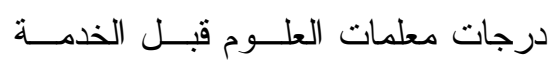

(عينة البحث) و المتوســـ الاعنبـاري

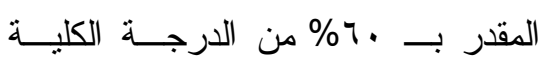

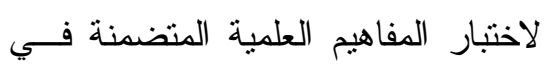
مناهج العلوم للمرحلة المتوسطة. - لا يوجـــد فــرق دال إحــصـائياً بـــين

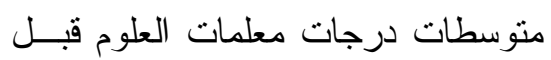

جدول (1)

\begin{tabular}{|c|c|c|c|c|}
\hline المجموع & قسم الفيزياء & قسم الكيمياء & قسم الأحياء & العينة \\
\hline ro & 1. & 1. & 10 & الاستطلاعية \\
\hline roo & $v$. & 10 & $1 \ldots$ & الأسساسية \\
\hline
\end{tabular}

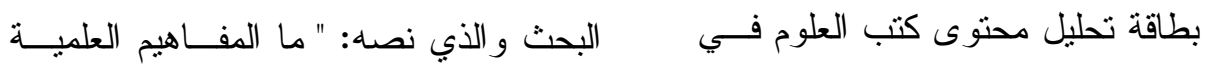

المرحلة المنوسطة. 
و • ثبات التحليل: قامــت الباحثـــة بعمليــة

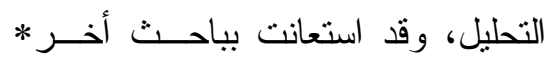

للقيام بعملية التحليل مع الباحثــة، وقــام

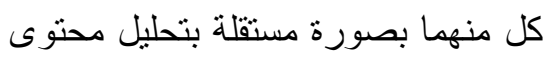

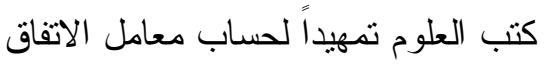

بين تحليل الباحثة و التحليل الآخر لتحديد

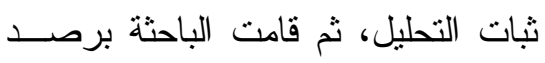

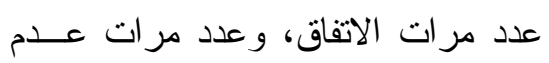

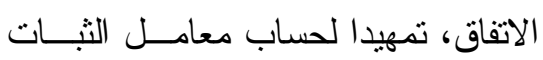

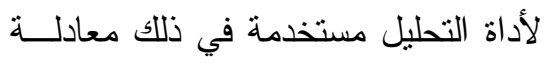

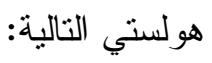

$$
\begin{aligned}
& \mathrm{R}=\frac{2(\mathrm{C} 12)}{\mathrm{C} 1+\mathrm{C} 2} \\
& \text { حيث تمثل: R: معامل الثبات. } \\
& \text { C12 عدد الفئــات المتفــق عليهـــا فـي } \\
& \text { التحليلين. } \\
& \text { C1 + C2 } \\
& \text { حلت في المرنين }
\end{aligned}
$$

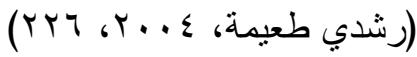$$
\text { وباستخدام المعادلة السابقة بلغ معامل }
$$$$
\text { الثبات بالنسبة لاتفــاق المحلـــين علــى أداة }
$$$$
\text { تحليل أهداف المو اطنة البيئية (01، ب9\%). }
$$

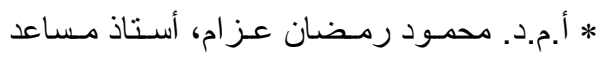

المنــاهج وطرق تـدريس العلوم بكليـة التربيـة

لالبنين جامعة الملك خالد.
المتضمنة فــي منــاهج العلــوم للمرحلـــة المتوسطة بالمملكة العربية السعودية؟ قامت

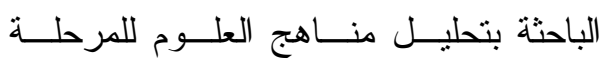

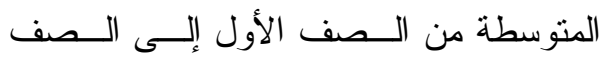
الثالث في المملكة العربية السعودية، مقتصرة

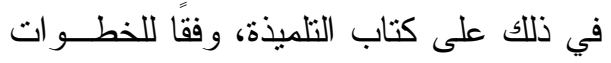

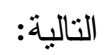
أ. تصميم أداة التحليل: وتكونت من محورين: الأفقي: خاص بالوحدات، و الر أسي: خاص بالمفاهيم العلمية. ب. هدف عملية التحليل: هدفت إلى تحديد المفاهيم العلمية المنضمنة فـــي منــاهج العلوم للمرحلة المتوسطة، التـي مـنـ

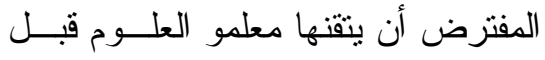

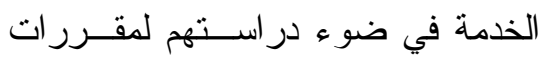

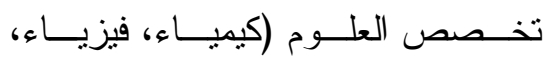

$$
\text { أحياء). }
$$

$$
\text { ج. وحدة التحليل: استخدم الموضوع }
$$

كوحدة لتحليل محتوى مناهج العلوم.

د. عينة التحليل: تكونت عينة التحليل التي استخدمتها الباحثة من (T) كتب للعلــوم

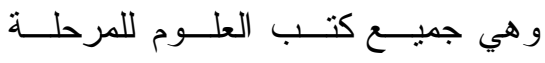
المتوسطة من الصف الأول حتى الصف الثالث بو اقع كتابين لكل صف در اسي. ه. فئة التحليل: تمنلت في المفاهيم العلمية. 
ز ـ نتائج التحليل: نوصـلت الباحثـة مــن العلمية المتضمنة في مناهج العلوم للمرحلـــة

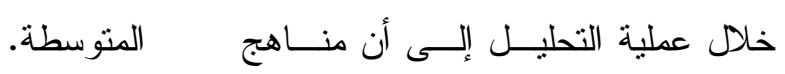

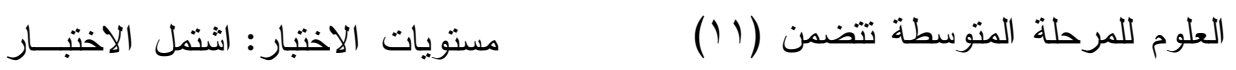

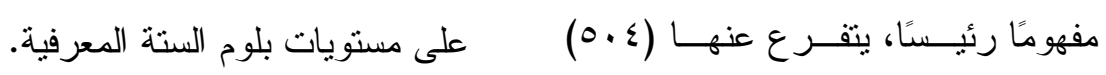
جدول مو اصفات الاختبار : تم إعــداد مفهومًا فرعيًا. وفي ضو ضود نتيجة التحليل

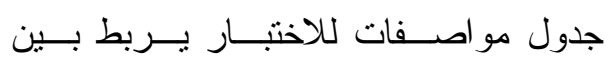
تم إعداد اختبار المفاهيم العلمية.

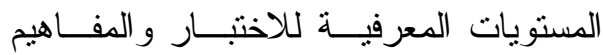
العلمية الرئيسة المتضمنة في مناهج العلـــوم اختبار المفاهيم العلمية المنضمنة في مناهج العلوم للمرحلة المتوسطة: هدف الاختبار : قياس مــدى تمكـن للمرحلة المتوسطة. معلمات العلوم قبل الخدمة مـن المفـــاهيم

جدول (r) مواصفات اختبار المفاهيم العلمية

\begin{tabular}{|c|c|c|c|c|c|c|c|}
\hline المجموع & التقويم & التركيب & التحليل & التطبيق & الفهم & التذكر & المفهوم / المستوى \\
\hline 7 & 7 & $\varepsilon$ & $r$ & 1 & r & 0 & النبات \\
\hline 7 & 1. & IT & 11 & 9 & $\wedge$ & V & الحيو ان \\
\hline 7 & 11 & Tr & 17 & $1 \leqslant$ & IV & 10 & البيئة \\
\hline 7 & rt & $r \varepsilon$ & r) & זr & $r$. & 19 & الطاقة \\
\hline 7 & r. & rq & rᄉ & rV & ro & r & الأرض \\
\hline 7 & rr & די & $r \varepsilon$ & ro & זr & r & الفضاء \\
\hline 7 & $\varepsilon r$ & rv & \& & $\varepsilon$. & rᄉ & rq & الخلية \\
\hline 7 & $\leqslant 0$ & $\varepsilon \varepsilon$ & $\leqslant 7$ & $\varepsilon r$ & $\varepsilon V$ & $\sum \wedge$ & طبيعة العلم \\
\hline 7 & or & $\leq 9$ & 01 & $0 \leqslant$ & or & 0 . & القوي \\
\hline 7 & 09 & 07 & 7. & 01 & ov & 00 & 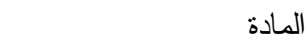 \\
\hline 1 & 74 & 70 & $7 \varepsilon$ & $\pi$ & rT & 71 & الإنسان \\
\hline 77 & 11 & 11 & 11 & 11 & 11 & 11 & الإجمالي \\
\hline
\end{tabular}


الاختبار صالحاً للتطبيق على أفـــــاد العينــة الاستطلاعية.

التجربة الاسنطلاعية للاختبار:طُبق الاختبار على العينة الاستطلاعية بلغ عددهم (ro) طالبة في الفصل الثاني للعام الدر اسي 

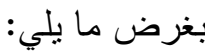

وضوح التعليمات و العبار ات: كانــــ و اضحة ولم يستفسر عنها أفر اد العينة. حساب معاملات السهولة و الصعوبة و التمييز : حذفت الاسئلة التي قلت عن ون

مستوى سهولة وصعوبة نز اوح ما بين (r, ·

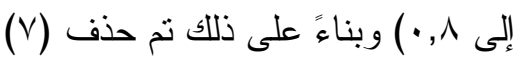

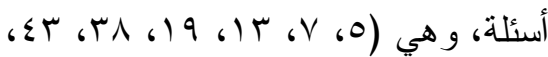

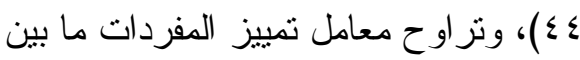

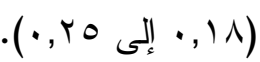
حساب معامل الثبات: تــم حسساب معامل ثبات الاختبار بطريقة ألفا كرونبــاخ لـاخ

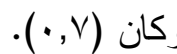

صدق الاختبار : نم حساب صدق الاختبـار

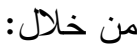

صدق المحكمين: من خلال عرضه على مجموعة من المحكمين في اســنطلاع للر أي، و أنثارت آر اؤهم إلى انتماء كل سؤ ال للمستوى المعرفي الذي وضع لقياسه، وكذلك

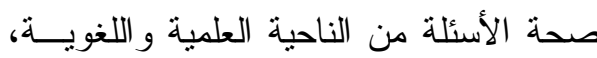

نــوع مفــردات الاختبـــار : أســـئلة

موضوعية من نمط الاختيار من متعـدد ذي

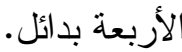

صياغة مفردات الاختبار : تكون كـلـل سؤ ال من جز أين رئيـسين، همـــا: مقدمـــة السؤ ال، وبديلات الإجابة، ثم رُتبت الأســئلة عشو ائيًا، وتكون الاختبار في صورته الأولية من (77) سؤالاً.

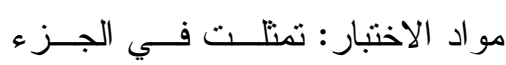
الأول كراسة الأسئلة، و الجزء الثاني نموذج لهان

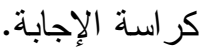

تقدير الدرجات وطريقــة تـصحيح الاختبار : أُعطيت لكل إجابة صحيحة درجــة

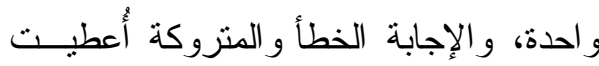

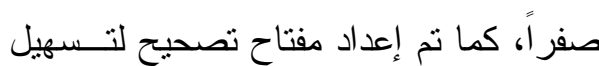

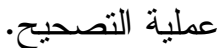
عرض الصورة الأولية للاختبار على

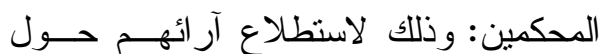

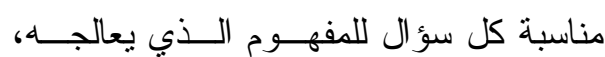
ومناسبة السؤال للمستوى المعرفي في ضوء تصنيف بلوم، وصحة الأسئلة مــن الناحيــة العلمية و اللغوية، ووضوح ح تعليمات الاختبار

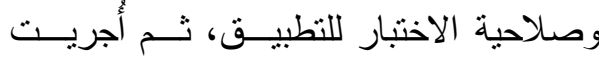
بعض التعديلات في صياغة بعض الأســـلة و العبار ات في ضوء آر اء المحكمين، و أصبح 
صدق الاتساق الداخلي: تم حسساب

ثيم معاملات الارتباط بين درجة المستويات

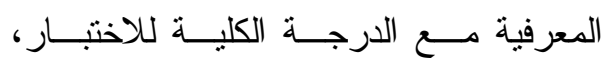

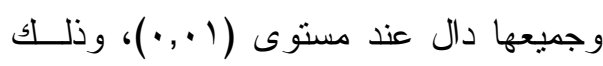

$$
\text { كما هي موضتح في جدول (ب) التالي. }
$$

جدول (广)

معاملات الارتباط بين درجات المستويات المعرفية والدرجة الكلية لاختبار المفاهيم العلمية

\begin{tabular}{|c|c|c|c|c|c|c|}
\hline التقويم & التركيب & التحليل & التطبيق & الفهم & التذكر & البيانات / المستوى \\
\hline$\cdot, V \leq r$ & $\cdot, 0 \mathrm{~V}$ & $\cdot, 099$ & $\cdot, 007$ & $\cdot, 70$. & $\cdot, T \vee r$ & قيم معامل بيرسون \\
\hline$\cdot, \cdot 1$ & $\cdot, \cdot 1$ & $\cdot, \cdot 1$ & $\cdot, \cdot 1$ & $\cdot, \cdot 1$ & $\cdot, \cdot 1$ & مستوى الدلالة \\
\hline
\end{tabular}

تم إعداد المقياس من خلال الخطوات الاختبار : تم حساب الزمن الــلازم لقـــر اءة التالية: هدف المقياس: قياس مدى توفر أبعاد حب الاستطلاع العلمي لاى عينة البحث. تحديد الأبعاد: ثم تحديــد(ع) أبعـــاد تعبر عن بعض أبعاد حب الاستطلاع العلمي

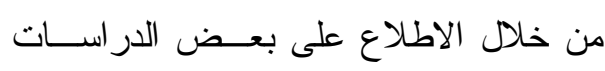

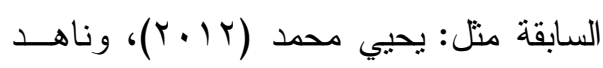

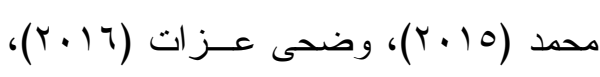

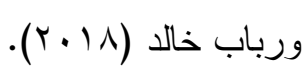
مو اصفات المقياس: وذلك كمـــا هــــ موضح في جدول (ع ) التالي. تعليمات الاختبار وهو حو الي(0) دقائق، وتم

مما يشير إلى أن الاختبار يقيس مـــا وضـــع لقياسه، وأنه بصلح للتطبيق على أفراد عينة البحث الأساسية. مسنوى الدلالة

حــــاب الـــزمن الـــلازم لتطبيــق

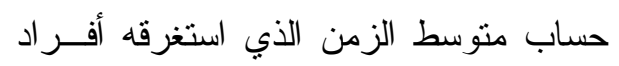
العينة الاستطلاعية في الإجابة عن الأســئة و هو حوالي (00) دقيقة، وبذلك فإن الــزمن الــن اللازم للإجابة عن المقياس ككل ( • ؟) دقيقة. الصورة النهائية للاختبار :

بلغ عدد مفردات اختبـــار المفــاهيم

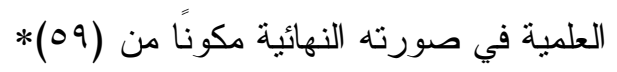
سؤالاً صالحًا للتطبيق كأداة للقياس في البحث مقياس حــب الاســتطلاع العلمــي لمعلمات العلوم قبل الخدمة

* ملحق (1) 
جدول ( ) ) مواصفات مقياس حب الاستطلاع العلمي

\begin{tabular}{|c|c|c|c|}
\hline 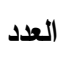 & أرقام المفردات & المفردات & أبعاد المقياس \\
\hline$\varepsilon$ & I I & الإيجابية & \multirow[t]{2}{*}{ الاهتمام بالموضوعات العلمية } \\
\hline$r$ & r & السلبية & \\
\hline$\varepsilon$ & 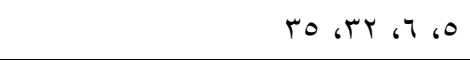 & الإيجابية & \multirow{2}{*}{ الموضوعة في الاطلاع على العلية } \\
\hline$r$ & 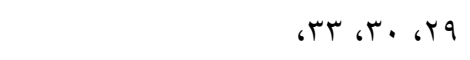 & 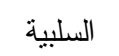 & \\
\hline$\varepsilon$ & $r \leqslant ، 9 ،$ ، $1 v$ & الإيجابية & \multirow[t]{2}{*}{ تقدير دور العلم و العلماء } \\
\hline$r$ & r & 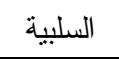 & \\
\hline$\wedge$ & 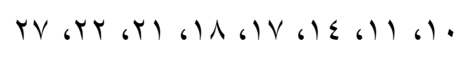 & الإيجابية & \multirow{2}{*}{ 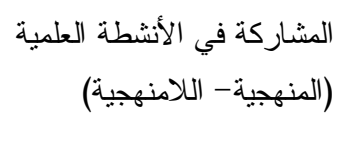 } \\
\hline 7 & ro, r $Y$, r. $17,110,1 T$ & 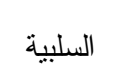 & \\
\hline ro & & & ال الإجمالي \\
\hline
\end{tabular}

مواد المقياس: تمثلت فــي الجـزءء

الأول كراسة الأسئلة، والجزء الثاني كراسة لهن

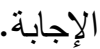

التجربة الاستطلاعية للمقياس: طُبق

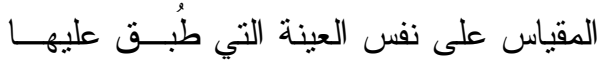

اختبار المفاهيم العلمية؛ وذللك بغرض:

وضوح التعليمات و العبار ات: وكانت

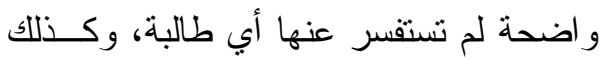

مفردات المقياس باستثاء توضيح معنى كلمة

أتقصنَّى في سؤ ال (1) وتم إيضاح معناها.

حساب معامل الثبات: نــم حسساب

معامل ثبات الاختبار بطريقة ألفا كرونبــاخ لتمات

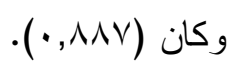

صياغة عبارات المقيــاس: روعـي

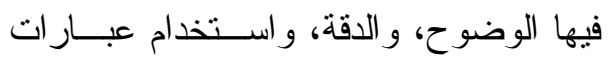

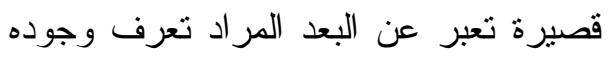

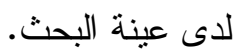

تقدير الدرجات: زود المقياس بتدرج

خماسي لتوفر البعد على النحو التالي (تتوفر بدرجة كبيرة جدًا، تتـــوفر بدرجـة كبيــــة تتوفر بدرجـة متوســة، تتـوفر بدرجــة صغيرة، تتوفر بدرجة صغيرة جدًا) و أُعطيت لتونة

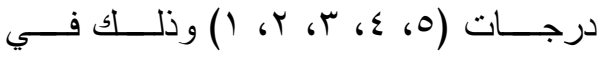
العبار ات الموجبة، في حين كان العكس فـي

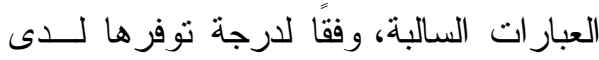

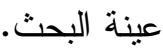


صورته النهائية من (ب0) عبــارة فرعيـة

حساب الصدق: تم بطريقتين:

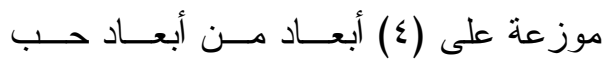
صدق المحكمــين: حبـــث عُـرض المقياس على مجموعة من المحكمين للتأكـــ الاستطلاع العلمي. صدق الاتساق الاخلي: تم حسساب قيم معاملات الارنباط بين درجـات أبعـاد العاد

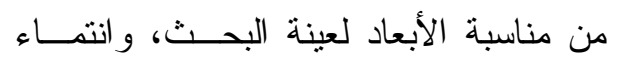

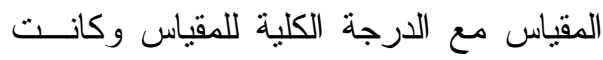

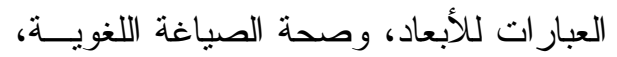
القيم دالة عند مستوى (1 (.,·)، وذللك كمس

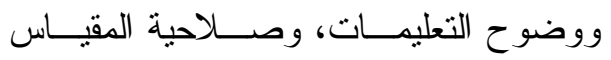

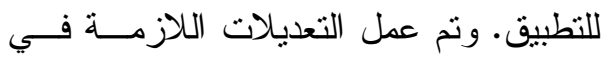
هو موضح في جدول (0) التالي.

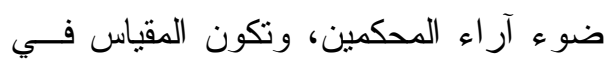

جدول (0)

قيم معاملات الارتباط بين درجات أبعاد المقياس مع الدرجة الكلية للمقياس

\begin{tabular}{|c|c|c|c|c|}
\hline المشاركة في الأشطة العلمية & تقدير دور العلم & على الموضبة في الاطلاع & بالموضوعات & البيانات / البعد \\
\hline$\cdot, 91$. & $\cdot, \wedge 9 \leq$ & $\cdot, q \cdot r$ & $\cdot, \wedge 94$ & قيم معامل بيرسون \\
\hline$\cdot, \cdot 1$ & $\cdot, \cdot 1$ & $\cdot, \cdot 1$ & $\cdot, \cdot 1$ & مستوى الدلالة \\
\hline
\end{tabular}

مفردة، و أصبح صالحًا للتطبيق كأداة لقيــاس حسـاب زمــن تطبيـق المقيــاس:

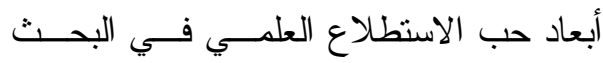

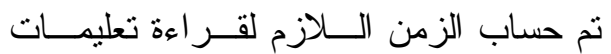

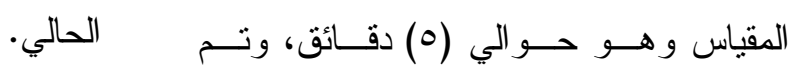
رابعًا: نطبيق أداتي البحـــث: قامـــت حساب متوسط الزمن الذي استغرقه أفــر اد اد

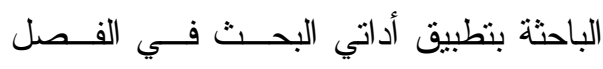

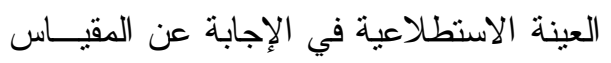

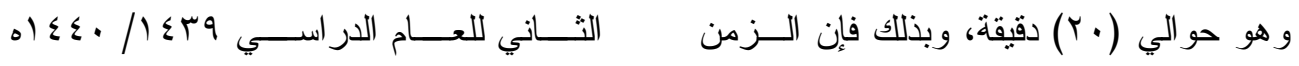

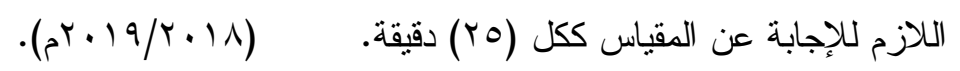
الصورة النهائية للمقياس: بلغ عدد

\section{خامسنا: نتائج البحث وتحليلها وتفسيرها:}

بعد الانتهاء من تطبيق أداتي القيــاس

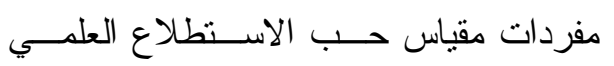

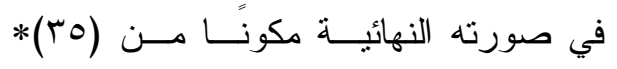

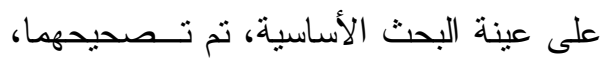


بين متوسط درجات معلمــات العلــوم قبــلـ الخدمة (عينة البحث) و المتوسط الاعتبــاري المقدر بـ • ٪\% من الدرجة الكلية لاختبــار

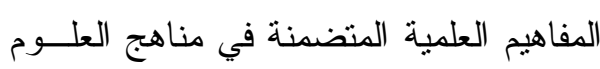
للمرحلة المتوسطة." ثم استخدام المتوسطات الحسابية واختبار (ت) لدرجات عينة البحث

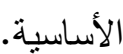

ورصدت النتائج في جداول نمهيدًا لمعالجتها

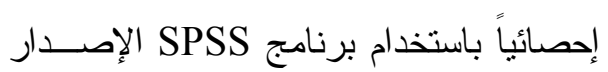

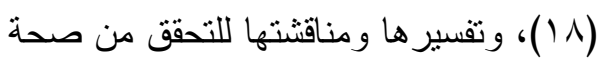

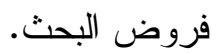

\section{عرض نتائج الفرض الأول وتحليلها وتفسيرها:}

للتحقق مــن صــــة الفــرض الأول و الذي نصه: " لا يوجد فرق دال إحـصـئياً

جدول (7)

المتوسط الحسابي وقيم (ت) لنتائج اختبار المفاهيم العلمية على عينة البحث (ن= ه० ب)

\begin{tabular}{|c|c|c|c|c|c|c|c|}
\hline مستوى الدلالة & قيمة ت & الانحر اف & المئوية & الاعتباري المتوسط & الحسابي & الارجة & مستويات الاختبار \\
\hline$\cdot, \cdot 1$ & $19, r r$ & $1, \leqslant 9$ & $r v, 0$ & $\varepsilon, \wedge$ & r & $\wedge$ & التذكر \\
\hline$\cdot, \cdot 1$ & rr, & 1,77 & $\varepsilon r, q$ & 7 & $\varepsilon, r q$ & 1. & الفهم \\
\hline$\cdot, \cdot 1$ & rr,qr & 1,70 & r., & 7 & $r, 7)$ & 1. & التطبيق \\
\hline$\cdot, \cdot 1$ & $\mid V, \varepsilon r$ & $1, \times 1$ & $\leq r, q$ & 7,7 & $\varepsilon, V Y$ & 11 & التحليل \\
\hline$\cdot, \cdot 1$ & 14,11 & 1,00 & $\varepsilon 0, V \vee$ & $0, \varepsilon$ & $\varepsilon, 1 Y$ & 9 & التركيب \\
\hline$\cdot, \cdot 1$ & $V, T Y$ & $r, 17$ & $0 ., 0$ & 7,7 & 0,07 & 11 & التقويم \\
\hline$\cdot, \cdot 1$ & Yo,01 & $\neg, \Upsilon_{A}$ & $\leq r, q$ & $r_{0, \varepsilon}$ & ro,r & 09 & الاختبار ككل \\
\hline
\end{tabular}

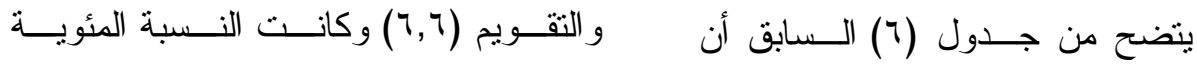
المتوسط الحسابي لارجات عينة البحث فـي ل لمتوسط درجات عينة البحث في مسستويات

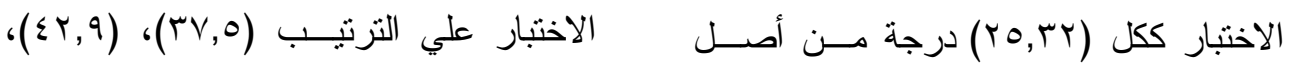

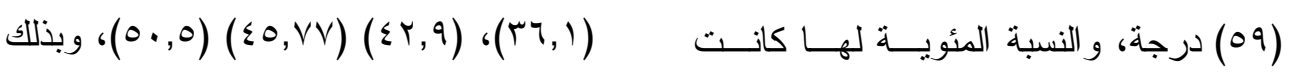

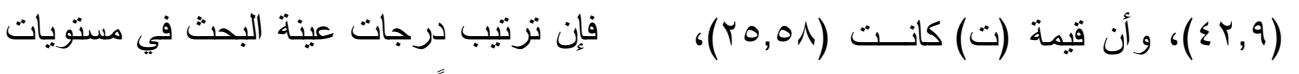

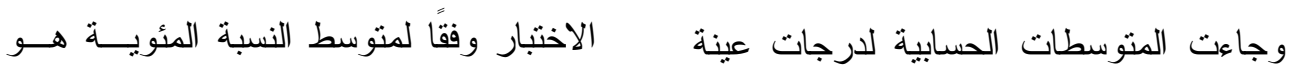

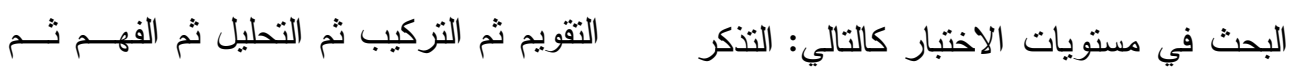

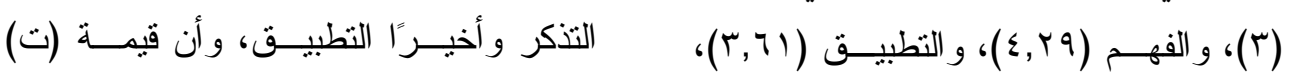

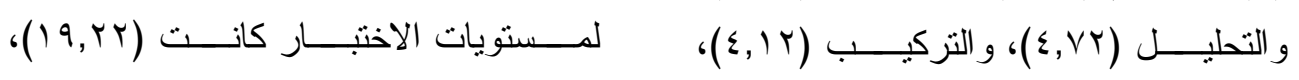


بكافة التخصصات (الفيزيـــاء، و الأحيــاء)، و غير كاف لإممام الطالبة بقسم الأحياء بكافة التخصصات (الكيمياء، و الفيزياء) وبالمنتل لإهل غير كاف لإملمام الطالبة بقسم الفيزياء بكافـــة

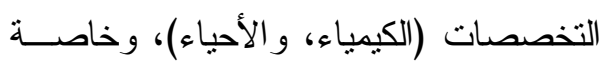

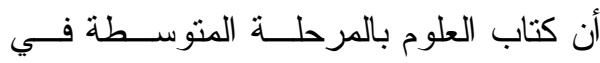

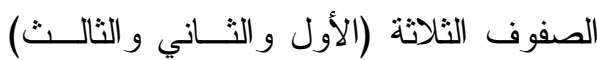
بتضمن كافة التخصصات. مقررات الأحبـــاء و الفيزيـــاء التــي

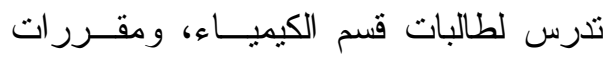

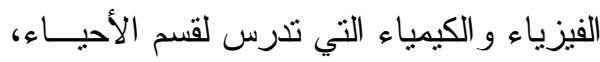
ومقررات الأحياء و الكيمياء التي تدرس لقسم لتصن الفيزياء يتم در استهم فــي المـستويين الأول

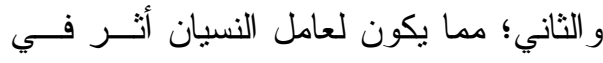
الاحتفاظ بهذه المفاهيم العلمية.

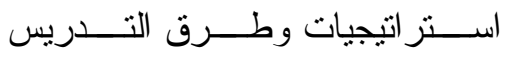

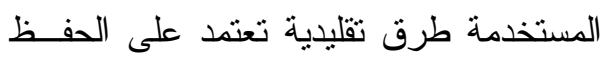

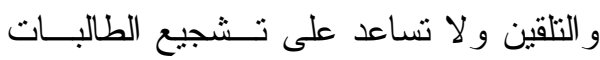

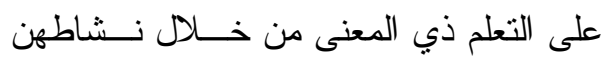

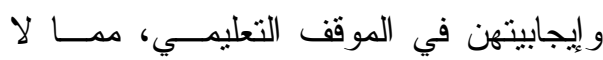

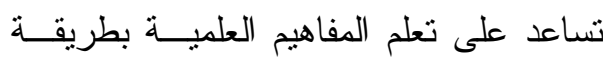

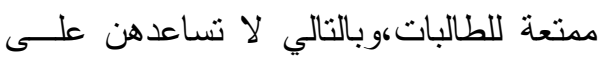
تذكر تلك المفاهيم وقت الحاجة إليها. وتتفق نتائج هذا البحث مع ما أثنارت إليه نتائج در اسة كل من: ozkan\&Akcay

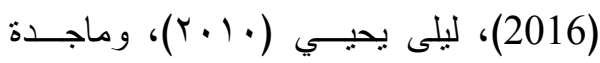

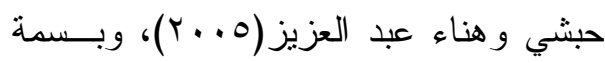

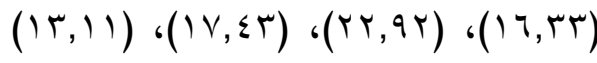

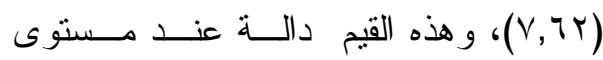
( ( ., •)، وتتير إلى وجود فرق بين منوسط درجات عينة البحث فـــي اختبــار المفــاهيم العلمية المتضمنة في مناهج العلوم للمرحلـــة

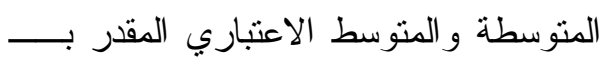
• . $\%$ من الدرجة الكلية للاختبار لــصالح

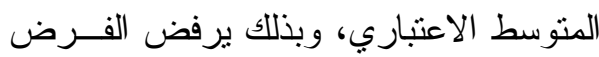

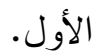
تفسير نتائج الفرض الأول: قد اتضح من الجدول السابق أن كل

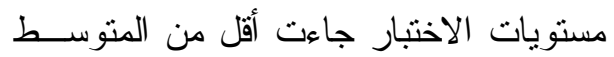

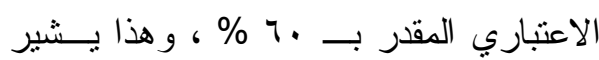
إلى تدني مستوى معلمات العلوم قبل الخدمة

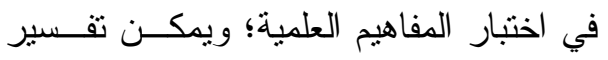
ذلك للأسباب التالية: عدد الساعات التذريسية المخصــصة في المستويين الأول و الثناني لدر اسة مقــرر الكيمياء العامة (ع) ساعات معتمدة، ومقرر الأحياء العامة (ع) ساعات معتمدة، ومقــرر الفيزياء العامة (ب) ساعات معتمدة، و عندما تتخصص الطالبة من المستوى الثالث فإنهــا تدرس فقط مو اد تخصصية بقسى الكيمياء

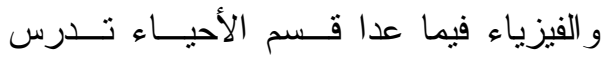
مقررين وهما: كيمياء عضوية (r) ساعات معتمدة، وكيمياء حيوية (r) ساعات معتمدة ، وهذا غير كاف لإممام الطالبة بقسم الكيمياء 


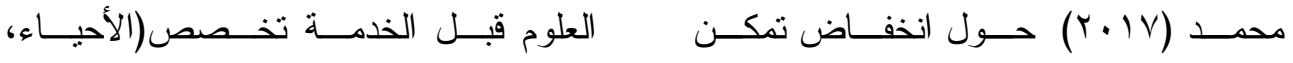

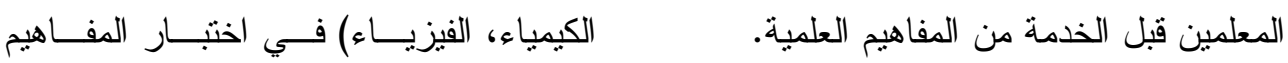

$$
\begin{aligned}
& \text { r.عرض نتـائج الفـرض التـاني العلمية". تم استخدام تحليل التباين الأحسادي }
\end{aligned}
$$

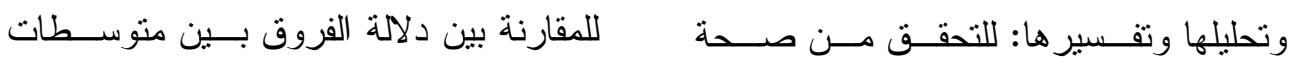

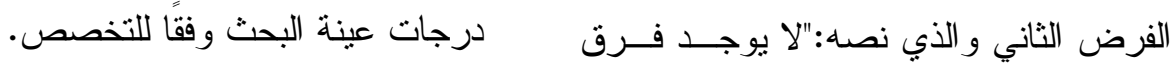

$$
\begin{aligned}
& \text { دال إحصائياً بين متوسطات درجات معلمات }
\end{aligned}
$$

جدول (v)

نتائج اختبار تحليل التباين لدلالة الفروق بين متوسطات درجات عينة البحث في اختبار

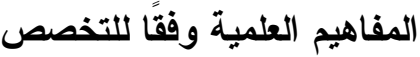

\begin{tabular}{|c|c|c|c|c|c|c|}
\hline مستوي & قيمة ف & متوسط المربعات & مجموع المربعات & الحرية & مصدر التباين & مستويات الاختبار \\
\hline \multirow{3}{*}{$\cdot, \cdots 1$} & \multirow{3}{*}{$\curlyvee, \wedge \wedge 9$} & $T \varepsilon, V Y Y$ & $r q, \varepsilon \leqslant$ & $r$ & بين المجموعات & \multirow{3}{*}{ التنكر } \\
\hline & & $r, I T V$ & $0 Y \wedge, 007$ & ror & داخل المجمو عات & \\
\hline & & & $071, \cdots$ & ros & الكلي & \\
\hline \multirow{3}{*}{ غير دال } & \multirow{3}{*}{$\varepsilon, \cdot 1 \leq$} & $1 \cdot, \wedge 0 \mathrm{~V}$ & $r,, V 10$ & $r$ & بين المجمو عات & \multirow{3}{*}{ الفهم } \\
\hline & & $r, v \cdot 0$ & $7 \Lambda 1,7 \pi \varepsilon$ & YOY & داخل المجمو عات & \\
\hline & & & $V \cdot r, r \leq q$ & TO\& & الكلى & \\
\hline \multirow{3}{*}{ غير دال } & \multirow{3}{*}{ 1, } & $M, \cdot 1$ & $V, \Sigma 9 V$ & T & بين المجمو عات & \multirow{3}{*}{ النطبيق } \\
\hline & & $r, v \leq q$ & $79 \cdot, 7 \cdot 0$ & rOY & داخل المجمو عات & \\
\hline & & $r, V \varepsilon$. & $79 \wedge, 1 \cdot r$ & TOS & الكلي & \\
\hline \multirow{3}{*}{ غير دال } & \multirow{3}{*}{$r, 7 r q$} & $v, 7 \wedge 1$ & 10, & $r$ & بين المجموعات & \multirow{3}{*}{ التحليل } \\
\hline & & $r, q 1$. & VTr,乏Yr & TOY & داخل المجمو عات & \\
\hline & & & $\vee \leqslant \wedge, \vee \wedge \varepsilon$ & ros & الكلي & \\
\hline \multirow{3}{*}{ غير دال } & \multirow{3}{*}{$1, \wedge r q$} & $\varepsilon, \varepsilon \cdot r$ & $\wedge, \wedge \cdot \varepsilon$ & $r$ & بين المجموعات & \multirow{3}{*}{ التركيب } \\
\hline & & $r, \Sigma \cdot T$ & $T \cdot T, \Sigma Y V$ & YOY & داخل المجموعات & \\
\hline & & & $T 10, Y M 1$ & ros & الكلي & \\
\hline \multirow{3}{*}{ غير دال } & \multirow{3}{*}{ r, rar } & 11,111 & YY,YYV & $r$ & بين المجمو عات & \multirow{3}{*}{ التقويم } \\
\hline & & $\varepsilon, 7 \leqslant 0$ & $11 V \cdot, \varepsilon 07$ & TOY & داخل المجمو عات & \\
\hline & & & ИЯr,TAr1 & ros & الكلى & \\
\hline \multirow{3}{*}{$\cdot, \cdots 1$} & \multirow{3}{*}{$7,9 \cdot V$} & $r T \cdot, N Y$ & or $1,7 \leq 0$ & $r$ & بين المجمو عات & \multirow{3}{*}{ الاختبار ككل } \\
\hline & & $r V, V T 0$ & $9017,7 \leqslant 1$ & YOY & داخل المجمو عات & \\
\hline & & & $1 \ldots r \lambda, r r q$ & TOS & الكلي & \\
\hline
\end{tabular}

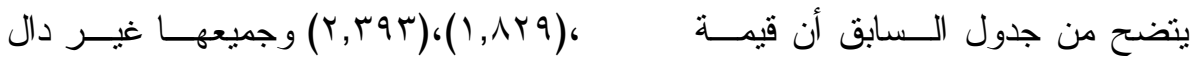

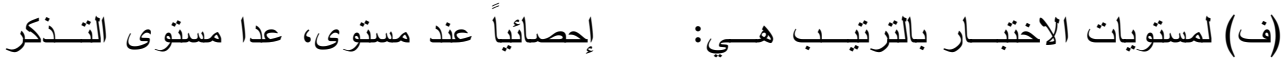

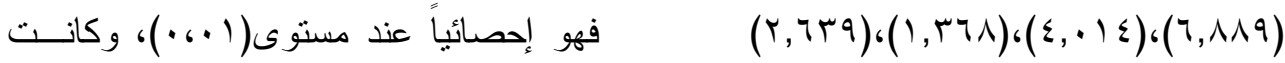

قيمة (ف) لمتوسطات درجات عينة البحــث 
في الدرجة الكلية للاختبـار هـي (7,9.v) درجات عينة البحث وفقًا لتخصصهم استخدم

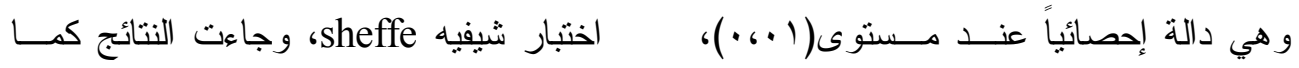
وللكثف عن مصدر الفروق بين متوسطات بالجدول التالي

(^) جدول (^)

اختبار "ثيفيه" للكثف عن مصدر الفروق وفقًا للتخصص جدول

\begin{tabular}{|c|c|c|c|c|c|}
\hline الفيزياء & البيولوجي & الكيمياء & المتوسط & التخصص & مستويات الاختبار \\
\hline$\cdot, \vee \leqslant \wedge \diamond V^{*}$ & $\cdot, 7 \leqslant$ TOr & - & $r, \varepsilon \uparrow \ldots$ & الكيمياء & \multirow{3}{*}{ التذكر التذر } \\
\hline., $1 \cdot 0 . \varepsilon$ & - & 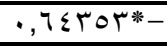 & $r, V \vee 70$ & الأحياء & \\
\hline- & $\cdot, 1 \cdot 0 \cdot \leq-$ & $\cdot, \mathrm{V} \leqslant \wedge \circ \mathrm{V}^{*}-$ & $r, T V I \leq$ & الفيزياء & \\
\hline$r, q 1 \ldots$ * & $r, 9 \leq 0 \varphi^{\circ *}$ & - & $r v, 11 \ldots$ & الكيمياء & \multirow{3}{*}{ الاختبار ككل } \\
\hline$\cdot, r \circ r^{\prime}-$ & - & $r, q \leq 0$ Yq*- & $r \varepsilon, 17 \leqslant V$ & الأحباء & \\
\hline- & $\cdot, \cdot$ rorg & $r, q 1 \ldots$ * - & $r \varepsilon, Y \ldots$ & الفيزياء & \\
\hline
\end{tabular}

تفسير نتائج الفرض الثاني:

يتضح من جدول (^) السابق ما يلي:

قد يرجع وجود فرق دال إحصائياً في

بالنسبة للفـروق بــين متوســطات

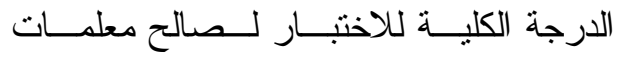

درجات عينة البحث في مستوى التذكر وفقًا

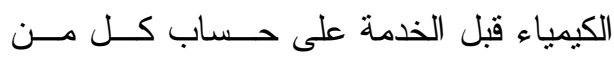

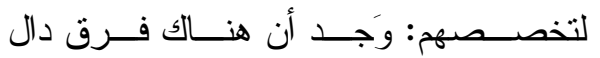

معلمات الفيزياء و الأحياء قبل الخدمة إلى أن

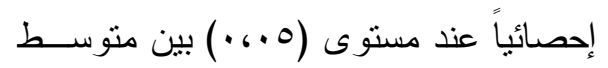

قسم الكيمياء تلتحق به الطالبات الحاصــلات التهاء

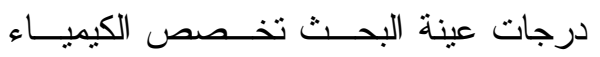

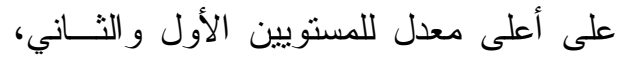

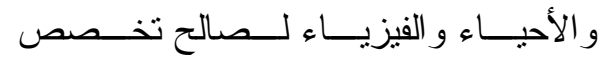

يليه قسم الفيزياء، و أقل معدل قعم الأحياء.

الكيمياء.

عرض نتــائج الفـرض الثاهـــث وتحليلهـــا

بالنسبة للفـروق بــين متوسـطات كاهـات

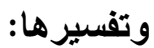

للتحقق من صــــة الفـرض الثالـــث

و الذي نصه: " لا يوجد فرق دال إحصائياً بين

متوسط درجات معلمات العلوم قبل الخدمـــة

(عينة البحث) و المتوسط الاعتباري

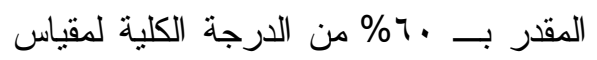

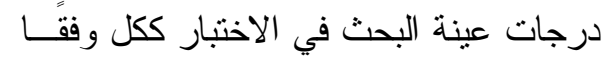

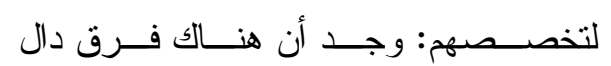

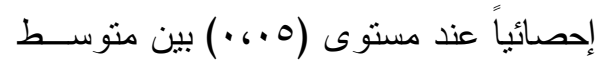

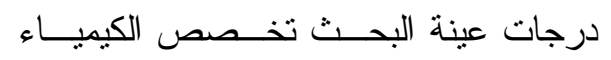

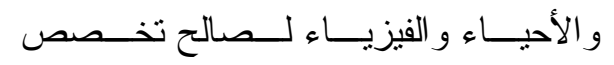

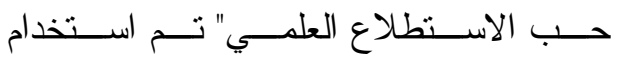

المتوسطات الحسابية واختبار (ت) لــدرجات

الكيمياء.

عينة البحث الأساسية. 
جدول (9 ) المتوسط الحسابي وقيم (ت) لنتائج مقياس حب الاستطلاع

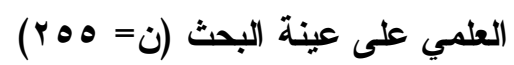

\begin{tabular}{|c|c|c|c|c|c|c|c|}
\hline مستوى الدلالة & قيمة ت & المعياري & المئوية & الاعتباري & الحستبط & الارجة & مستويات المقياس \\
\hline.,$\ldots 1$ & r r, ^o. & r,VOVTr & vo,ru & r) & Yч, YVYO & ro & الاهتمام بالموضو عات العلمبة \\
\hline.,$\ldots 1$ & $1, r, 499$ & $\varepsilon, r v \ldots r$ & $V_{\cdot}, \varepsilon V$ & r) & Y & ro & الموضو عات العلمية الاطــلاع علـى \\
\hline,$\ldots$, & $7,0.0$ & $\varepsilon, 1$ AVqA & $T \leq, \wedge \Lambda$ & r) & $r Y, Y . \Delta q$ & ro & تقدير دور العلم والعلماء \\
\hline$\cdot, \cdots$, & K, & $v, \cdot r \wedge v r$ & 74,17 & $\varepsilon r$ & $\varepsilon V, V \backslash T V$ & $v$. & 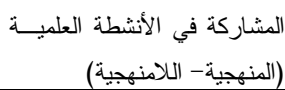 \\
\hline.,$\ldots 1$ & $17, \leqslant \vee V$ & $10,900 \cdot 1$ & $79, \varepsilon 1$ & 1.0 & $|r|, \varepsilon T Y V$ & ivo & المقياس ككل \\
\hline
\end{tabular}

النسبة المئوية هو الاهتمــام بالموضــوعات

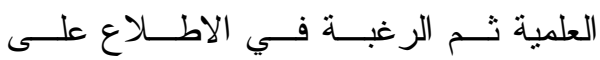

يتضح من جـدول (9) الــسابق أن

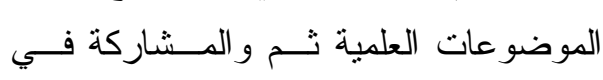

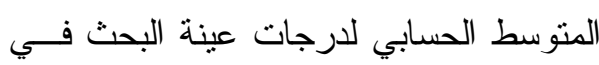

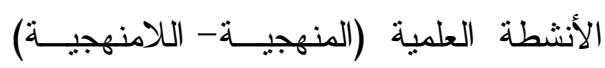

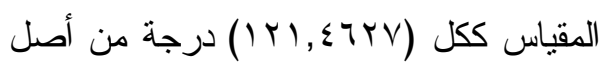

وأخيرًا وتقدير دور العلم و العلماء، وأن قيمة

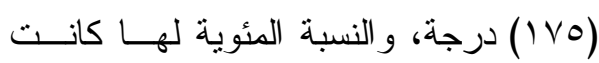

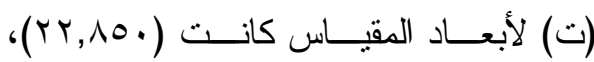

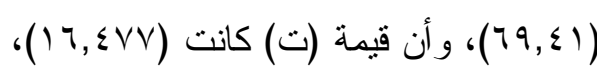

(1)

وجاءت المتوسطات الحسابية لارجات عينة

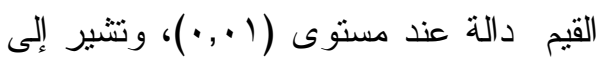

البحث في أبعاد المقياس كالتــالي: الاهتمـــام

وجود فرق بين متوسط درجات عينة البحث

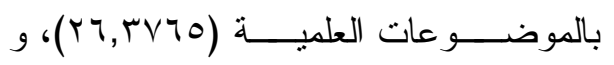

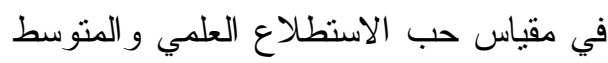

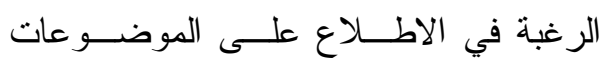

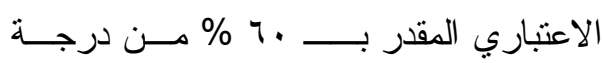

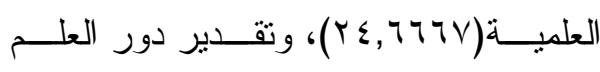

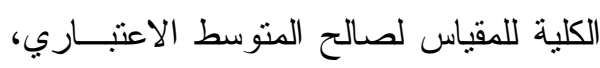

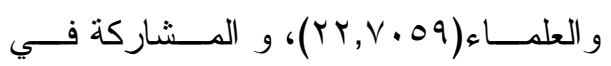

الأنشطة العلمية (المنهجيــة- اللامنهجيـــة)

وبذلك برفض الفرض الثالث.

( ) ( $)$ وكانت النسبة المئوية لمتوسط

تفسير نتائج الفرض الثالث:

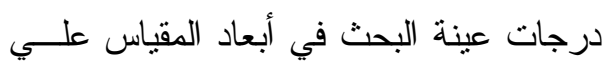

قد يرجع انخفاض درجات معلمـات

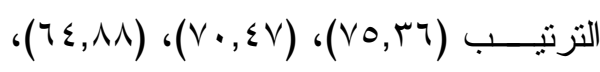

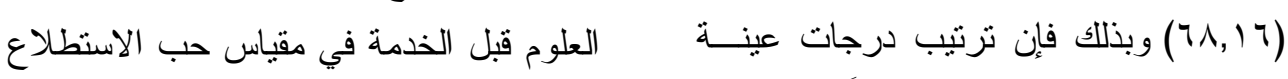

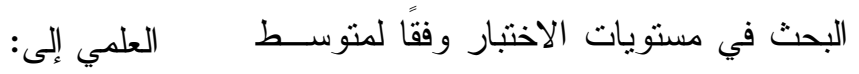


عدد الطالبات المسجلات فــي كـلـ

مجموعة داخل المعمل يكون عــدد كبيــر ،

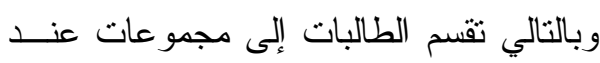
إجر اء التجارب وبالتــالي لا تقــــوم الطالبـــة بإجر اء التجربة بنفسها، و هذا قد يؤثز علـى على امتلاكهن لأبعاد حب الاستطلاع.

عدد الطالبــات المــسجلات داخـلـ

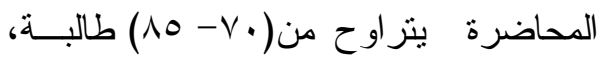
وبالتالي يصعب على المعلمة توزيـــع أوراق عمل داخل المحاضرة يتضمن أنشطة و أسئلة ومو اقف قد تسهم فـي تتميــة أبعــاد حــب الاستطلاع العلمي لديهن.

وتتفق نتائج البحث مع نتائج در اســة

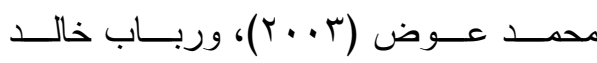

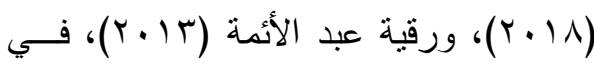
حين اختلفت مع نتائج در اسة كل من: ثتــاء

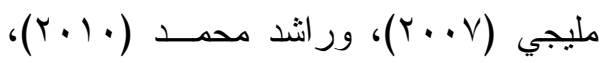
وميادة طارق (11 (r) التي أثنارت نتائجها إلى فاعلية طــرق و اســـر اتيجيات ونمـــاذج التــدريس المـسـتخدمة فــي تتمبــة حــبـ الاستطلاع العلمي، لكنها كانــت در اســات تجريبية.

ع. عرض نتائج الفرض الرابــع وتحليلهـــا

$$
\text { وتفسير ها: }
$$

للتحقق من صحة الفــرض الرابــع

و الذي نصه:" لا يوجد فرق دال إحصائياً بين متوسطات درجات معلمــات العلــوم قبـلـل
قلة عدد الساعات العملية المخصصة

لكل تخصص (كيمباء، و الأحياء، و الفيزياء) في برنامج إعدادهن؛ حيث أن عدد الوحدات العملية لقسم الكيمياء تبلغ (1) وحدة معتمدة،

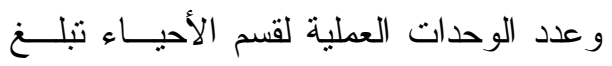
(Y ) وحدة معتمدة، و عدد الوحدات العمليــة لقسم الفيزياء (^) وحدات معتمدة؛ مما قــــ يؤثز بالسلب على اكتسابهن للمعارف العلمية و التي قد تؤثز على امتلاكهن لأبعـاد حــب لتب الاستطلاع.

أن طرق التدريس المـسـتخدمة فــي برنامج الإعداد تعتمــد علــى المحاضـــر ات

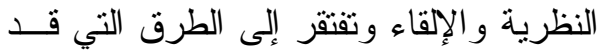
تساعد على تتمية حب الاستطلاع العلمــي، التي قد تزيد من امستناكهن لأبعــاد حــب الاستطلاع العلمي.

عدم تعود عينة البحث منذ الـسنوات الدر اسية الأولى، وبخاصة في المر احل مــــا قبل الجامعية على ممارسة مهـــام و أنــشطة تؤدي بدور ها إلى امــتلاكهن لأبعــاد حــب الاستطلاع العلمي. تعتبر المعرفة و الفهــم و التحــصيل الأكاديمي مؤشر ات أسـاســية لتتميــة حــبـ الاستطلاع العلمـي، وحبــث أن مـستوى

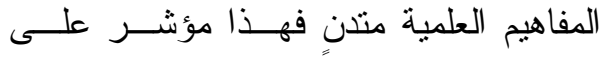
انخفاض درجات عينة البحث ف فـي مقيــاس حب الاستطلاع العلمي. 
الخدمة تخصص (الأحياء، الكيمياء، الفيزياء) دلالة الفروق بين منوسطات درجات عينــة

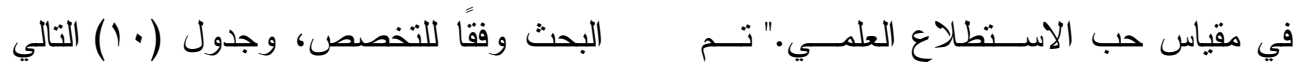

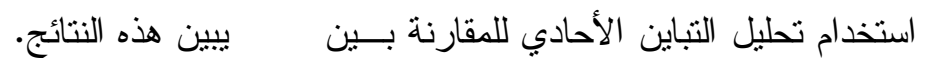

$$
\text { جدول (1.) }
$$

نتائج اختبار تحليل التباين لدلاية الفروق بين متوسطات درجات عينة البحث في مقياس

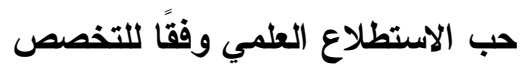

\begin{tabular}{|c|c|c|c|c|c|c|}
\hline مستوى الدلائ & قيمة ف & متوسط & المربعوع & الحرية & مصدر التباين & مستويات المقياس \\
\hline \multirow{3}{*}{ غير دال } & \multirow{3}{*}{0,109} & $V_{\cdot}, 011$ & $1 \leqslant 1, \cdot 47$ & r & بين المجموعات & \multirow{3}{*}{ الاهتمام بالموضو عات } \\
\hline & & IT,TV. & $\Gamma \varepsilon \varepsilon \varepsilon, \wedge r \Gamma$ & ror & داخل المجموعات & \\
\hline & & & ro10,109 & ros & الكلى & \\
\hline \multirow{3}{*}{ غير دال } & \multirow{3}{*}{$1, \wedge$. } & $r \cdot, T \cdot q$ & $\varepsilon 1, r \backslash \vee$ & r & بين المجموعات & \multirow{3}{*}{ الرغبة في الاطلاع على العلى } \\
\hline & & $19, .01$ & $\varepsilon \wedge .9, \varepsilon \leqslant 9$ & ror & داخل المجموعات & \\
\hline & & & $\Sigma \wedge 0 \cdot, 7 T \vee$ & ros & الكلي & \\
\hline \multirow{3}{*}{ غير دال } & \multirow{3}{*}{ r, rYq } & $\{\cdot, \varepsilon r \mid$ & $\wedge \cdot, \wedge \leqslant 1$ & r & بين المجموعات & \multirow{3}{*}{ تقدير دور العلم والعلماء } \\
\hline & & IV, rod & $\varepsilon r v \varepsilon, 1 \ldots$ & ror & داخل المجموعات & \\
\hline & & & $\leq \varepsilon 0 \leqslant, 9 \leqslant 1$ & ros & الكلى & \\
\hline \multirow{3}{*}{ غير دال } & \multirow{3}{*}{$1, \cdot 4$} & $01, . \varepsilon$. & I. r, . A. & r & بين المجموعات & \multirow{3}{*}{ المشاركة في الأنشطة } \\
\hline & & $\leq 9$, orr & $M \leq \Lambda r, \cdot r r$ & ror & داخل المجموعات & \\
\hline & & & ITON $\varepsilon, 1 \cdot r$ & ros & الكلي & \\
\hline \multirow{3}{*}{ غير دال } & \multirow{3}{*}{$r, I T V$} & ory, & $1 \cdot V r, \varepsilon V$. & r & بين المجموعات & \multirow{3}{*}{ المقياس ككل } \\
\hline & & TOY,TYO & דropo,qrT & ror & داخل المجمو عات & \\
\hline & & & $7 \leq 709, \Upsilon 97$ & ros & الكلى & \\
\hline
\end{tabular}

يتضح من جدول الـسابق أن قيمــة تفسير نتائج الفرض الرابع:

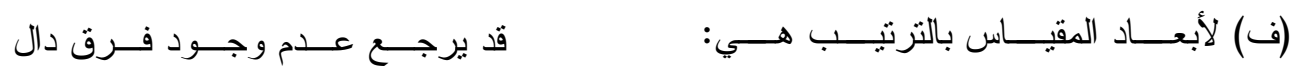
(Y.

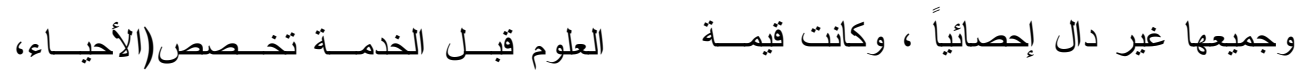

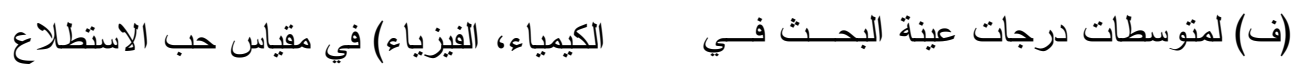

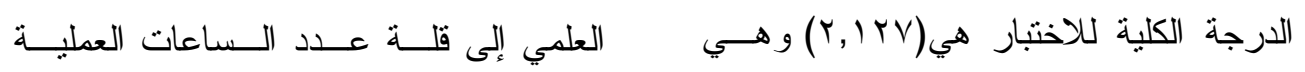

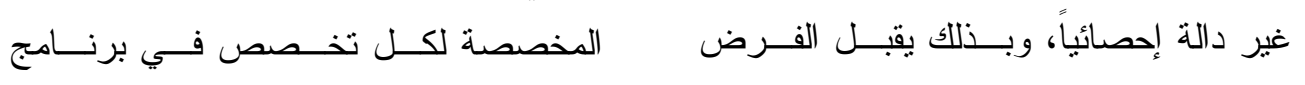

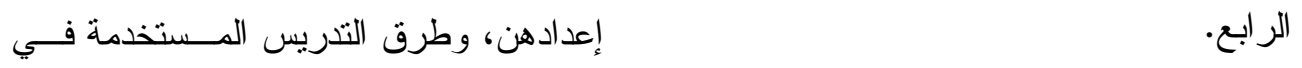


تخصص (كيمياء - فيزياء- أحياء) لــصالح

معلمات قسم الكيمياء على حساب معلمــاء فياء

قسمي الفيزياء و الأحياء في اختبار المفــاهيم

العلمية.

أظهرت النتائج عدم وجود فــرق دال

إحصائياً بين منوسطات درجات عينة البحث

تخصص (الفيزياء - الأحياء) فــي اختبــار

المفاهيم العلمية.

أظهرت النتائج انخفــاض مـسـتوى

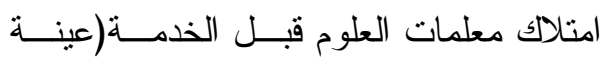

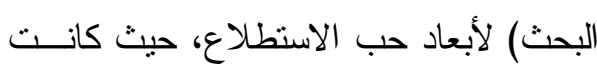

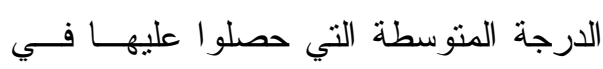

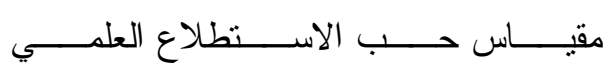

(I T), STYYV)

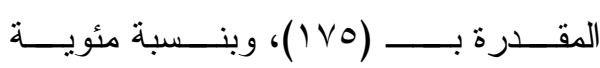

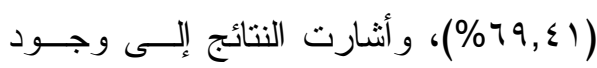

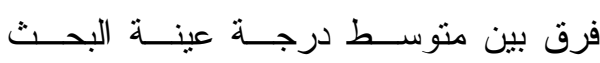

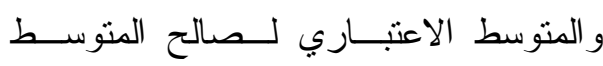

الاعتباري.

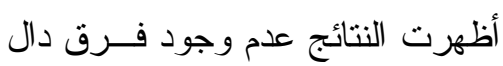

إحصائياً بين منوسطات درجات عينة البحث

تخصص (الكيمياء- الفيزياء- الأحياء) فـي لـي دئي

مقياس حب الاسنطلاع العلمي.

سادسًا ـالتوصيات والبحوث المقترحة:

توصيات البحث: في ضوء النتـائج

السابقة، يوصي البحث بما يلي:

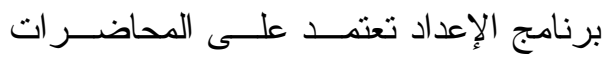

النظرية و الإلقاء، وتتفيذ الأنشطة المنهجيـــة

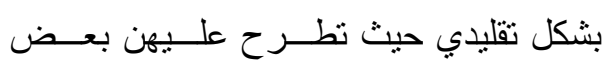
الأسئلة ذات الصلة بما يدرس ونتتم الاجابــة عليها بشكل مباشر دون البحث و الاستقصاء، و عدم تتفيذ الأنشطة اللامنهجية.

\section{تعقيب على نتائج البحث:}

توصل البحث الحالي إلى ما يلي:

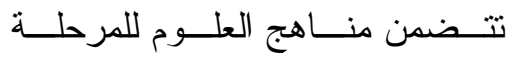

المتوسطة في المملكة العربية السعودية (1)

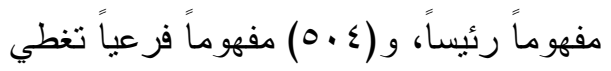
مجالات البيولــوجي و الفيزيـــاء و الكيميــاء و الأرض و الكون. - مالات اليرو

أظهرت معلمات العلوم قبل الخدمـــة

(عينة البحث) مستوى منخفضاً في تمكـنهن من المفاهيم العلمية المتضمنة فــي منــاهج

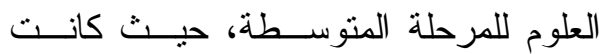
الدرجة المتوسطة التي حصلن عليهــا فــي اختبار المفاهيم العلمية ضعيفة، إذ حــصلن

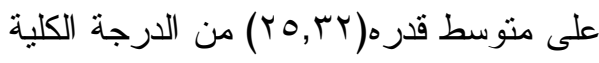

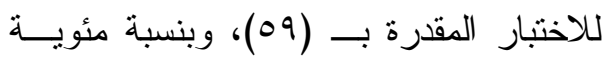

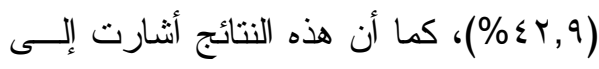

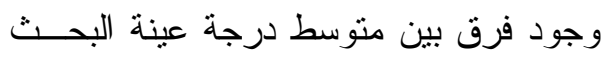

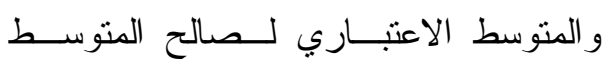

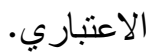

أظهرت النتــائج وجـــود فــرق دال إحصائياً بين منوسطات درجات عينة البحث 


$$
\begin{aligned}
& \text { إعادة النظر فـي توزيــع الـساعات من مهار ات الاستقصاء العلمــي أو التفكيـر }
\end{aligned}
$$

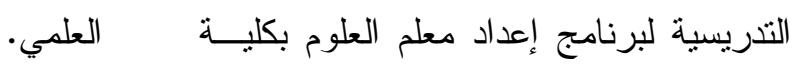

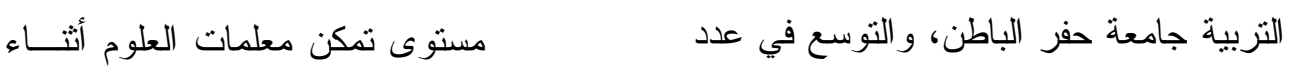

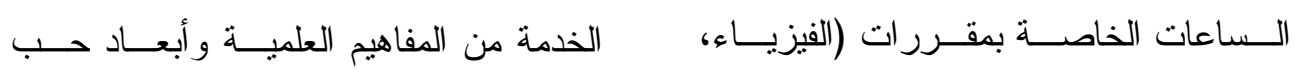

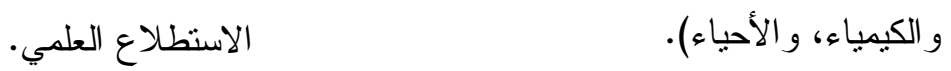

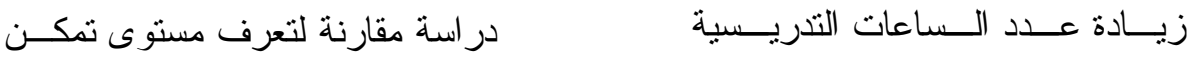

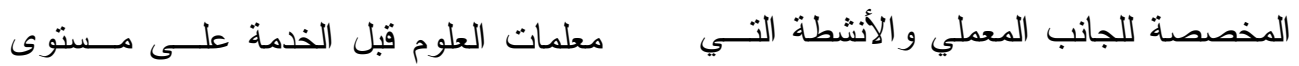

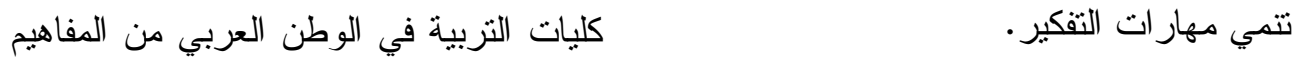

$$
\begin{aligned}
& \text { محاولة الموازنة بين الخطة التدريسية العلمية وأبعاد حب الاستطلاع العلمي. } \\
& \text { در اسة مقارنة لتعرف مستوى تمكـن } \\
& \text { معلمي العلوم قبل الخدمة على مستوى كليات }
\end{aligned}
$$

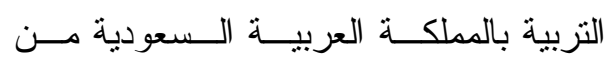

$$
\begin{aligned}
& \text { المفاهيم العلمية وأبعــاد حــب الاســنطلاع باله } \\
& \text { العلمي. } \\
& \text { أنز وحدة مقترحة في العلوم في تتمية }
\end{aligned}
$$

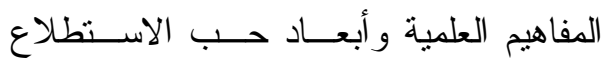

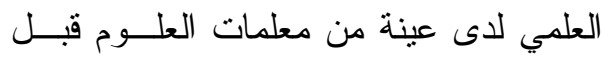

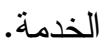

$$
\begin{aligned}
& \text { أثز وحدة مقترحة في الأحيــاء فـي } \\
& \text { تتمية المفاهيم العلمية وأبعاد حب الاستطلاع فئر الاحه }
\end{aligned}
$$

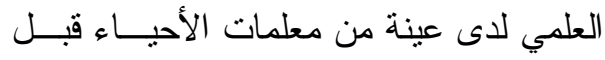

$$
\begin{aligned}
& \text { الخدمة. - المي }
\end{aligned}
$$

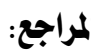

$$
\begin{aligned}
& \text { 1. ابتسام ناصر هويميل، وعبير مبــارك }
\end{aligned}
$$

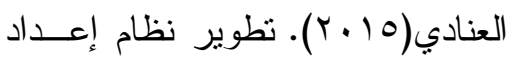

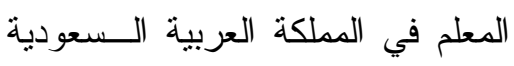

$$
\begin{aligned}
& \text { في ضوء تجربتي اليابــان وفنلنـــــا، } \\
& \text { القائمة لبرنامج إعداد معلم العلوم في كليــة } \\
& \text { التربية جامعة حفر الباطن و المناهج الدراسية } \\
& \text { في مر احل التعليم المختلفة. } \\
& \text { مر اجعة الأنشطة التعليميـــة وطـــرق }
\end{aligned}
$$

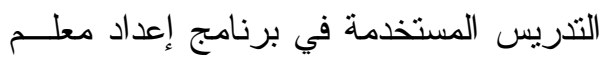

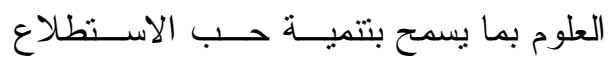

$$
\begin{aligned}
& \text { العلمي لدى الطلاب الملتحقين بالبرنامج. } \\
& \text { تقليل عدد الطالبات المـسجلات فـي } \\
& \text { كل مجموعة؛ ليسهل استخدام اســتر اتيجيات } \\
& \text { وطرق التدريس الحديثة. } \\
& \text { إعداد دورات وورش عمل لأعضاء } \\
& \text { هيئة التدريس بالأقسام العلمية على اســتخدام } \\
& \text { استر اتيجيات التعلم النشط. } \\
& \text { البحوث المقترحة: يقترح البحــث إمكانيــة } \\
& \text { إجراء البحوث التالية: } \\
& \text { مستوى تمكن معلمات العلـــوم قبـــلـ } \\
& \text { الخدمة في كلية التزبية جامعة حفر البــاطن }
\end{aligned}
$$


السعودية للعلوم التزبويـــة و النفــسية

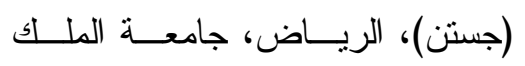
سعود 7. بـسمة محمــد عرســان الكيلانـــي

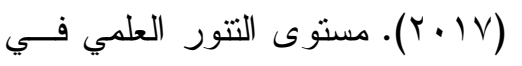

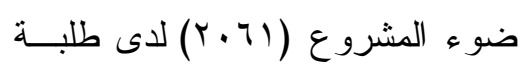

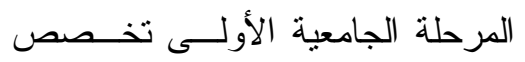

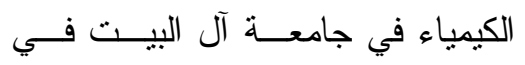

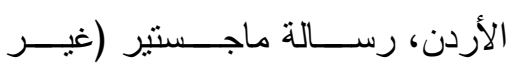
منشورة)، كلية العلوم التربوية، جامعة رله

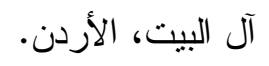

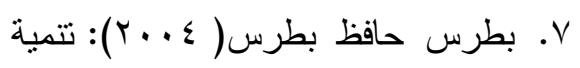

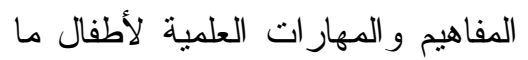
قبل المدرسة، عمان، دار المسيرة.

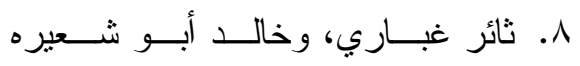

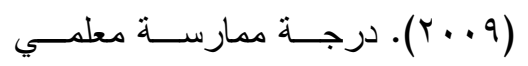

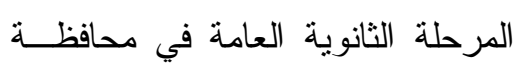

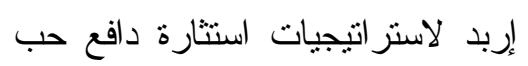

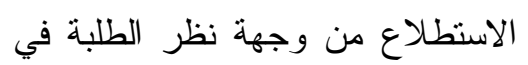

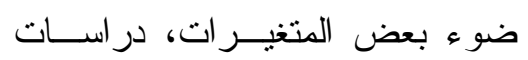

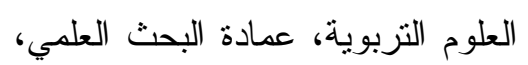
الجامعي الاردنية، المجلد(بr).

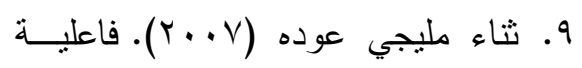

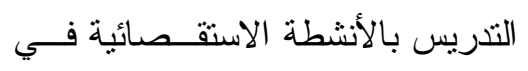

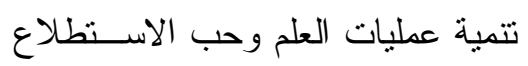
العلمي و الاتجاه نحو التعلم التعـاوني

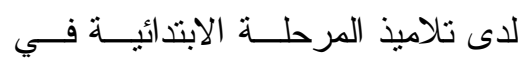

المجلة التربوية الدولية المتخصـصـة،

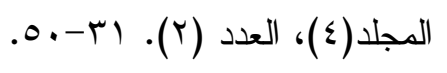

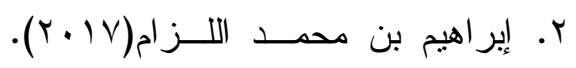

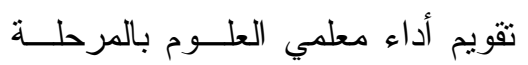

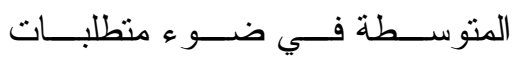

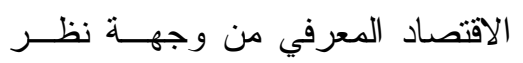

المعلمين، مجلة كلية التربية، جامعــة وجنة

طنطا، العدد(1)، المجلد(10)،الجـزئهر

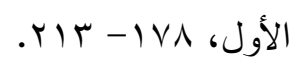

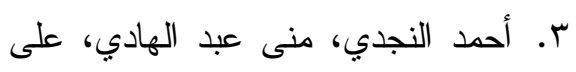

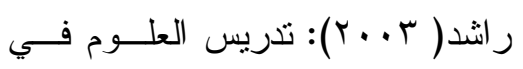

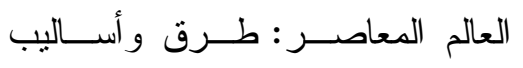

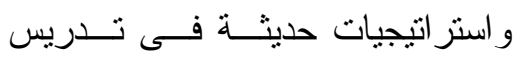

العلوم، القاهرة، دار الفكر العربي.

ع. أسماء محمد القطيم(10 (Y). تقــويم

الأداء التدريسي لمعلمــات الأحيـاء

للمرحلة الثانوية بمحافظة المجمعة في لأني

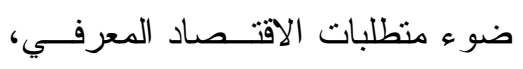
رسالة ماجستير (غير منشورة)، كلية

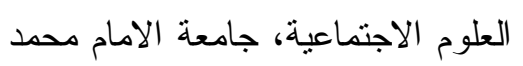

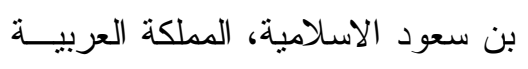

السعودية.

ه. إيمان محمد الرويثي، تهاني الرؤســاء

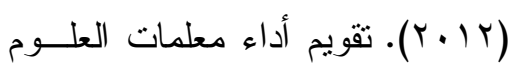

في تدريس منهج العلوم للصف الأول

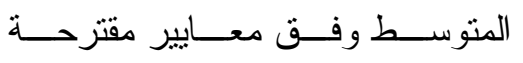

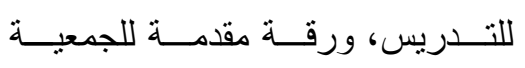




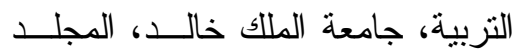

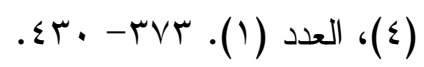

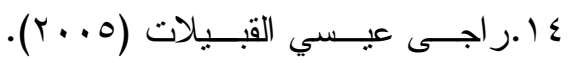

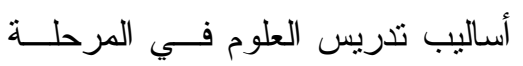

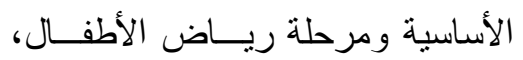

$$
\text { عمان، د دار الثقافة. }
$$

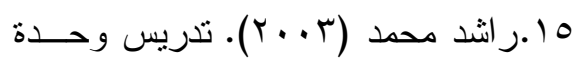

في العلوم قائمة على ممارسات التعلم

الذاتي لتتمية مهار ات البحث العلمــي فماني

وحب الاستطلاع لدى نلاميذ المرحلة

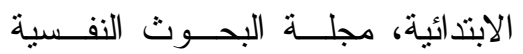

و التزبوية، كليــة التربيــة، جامعــة التبـة

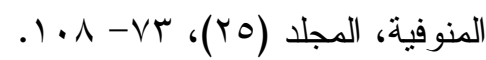

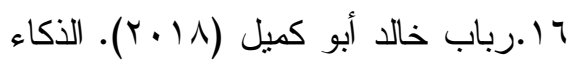

الوجداني وعلاقته بكل مــن دافعيــة

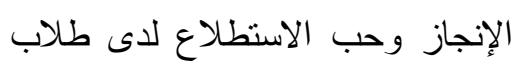

جامعــة القـــس المفتوحسـة، رســــال

ماجستير ، الجامعة الاسلامية، غزة.

V ا.رشدي أحمد طعيمة (ع ... Y). تحليل

المحتوى في العلوم الإنسانية مفهومه-

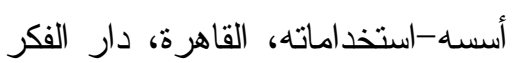

$$
\text { العربي. }
$$

1 ا.سناء محمد ضـــف الله أبــو عــاذرة

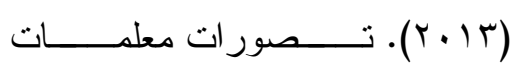

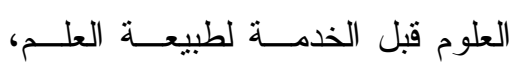

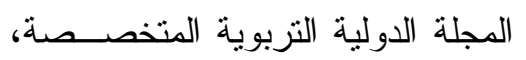

ضوء برنامج STC، مجلـــة التربيـــة

العلمية، الجمعية المــصرية للتربيــة فيـة

العلمية، المجلــد (·• ()، العـدد (r)،

$.17 r-1 . V$

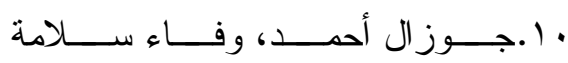

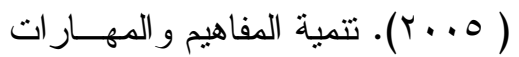

العلمية لطفل الروضة، القاهرة، عــالم

$$
\text { الكتب. }
$$

11 ا.حسام الدين العزوني (rا.بr). فاعلية

نموذج رحلة التدريس في فهم مفاهيم

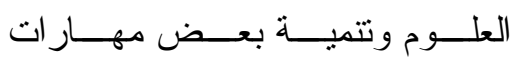

الاستقصاء وحب الاستطلاع العلمـي بــي

لدى تلاميذ المرحلة الإعدادية، رسالة

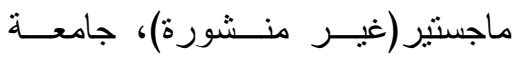

طنطا.

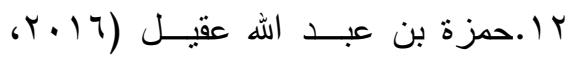

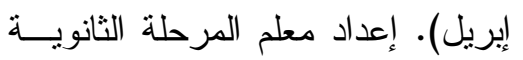

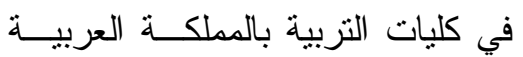

السعودية في ضوء معــايير الجــودة

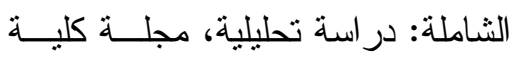

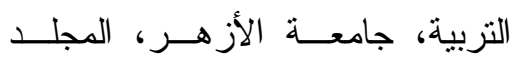

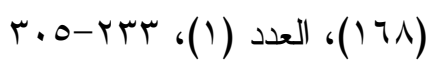

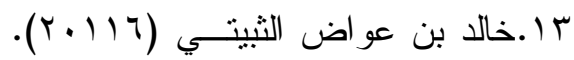

تطوير بر امج إعداد المعلم بالجامعات

السعودية في ضوء التجارب العالمية.

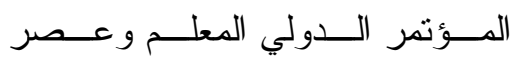

المعرفة: الفرص و التحــديات. كليــة 
معلمي الكيمياء و الأحياء قبل الخدمــة

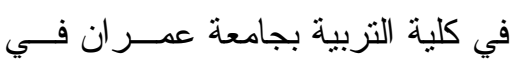
الجمهورية اليمنية، المجلـــة العربيــــة للتزبية العلمية و التقنية، جامعة العلوم

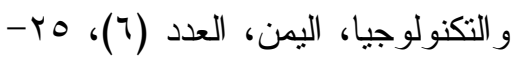

Or.عبد السلام مــصطفى عبــد الـسلام

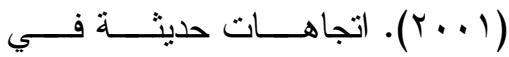
تذريس العلوم، القـــاهرة، دار الفكــر

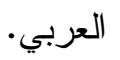

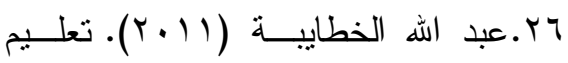
العلوم للجميع (ط.ب). الأردن. عمّان:

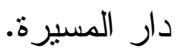

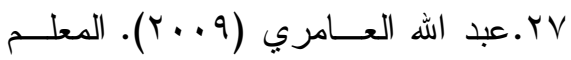
الناجح. عمّــان: دار أســامة للنــشر و التوزيع.

^r.عبد الله محمــد عثـــان المخلاقـي

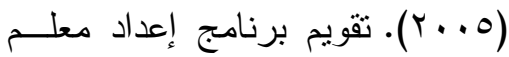

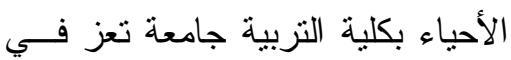
ضوء الاتجاهات التربوية المعاصرة، لهاءه

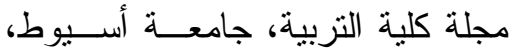

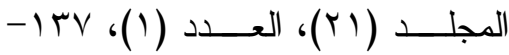
.1 Vo

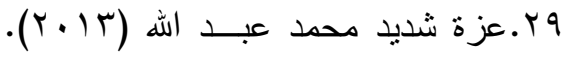
تقويم أداء الطلاب معلمي العلوم بكلية

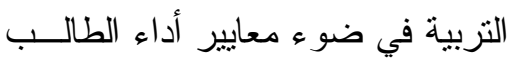

دار ســمات للار اســـات و الأبحـــاث،

،( $\varepsilon)$

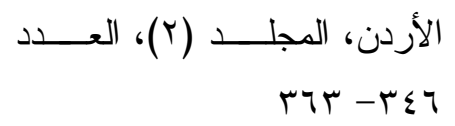

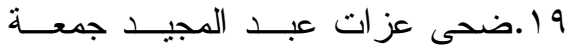

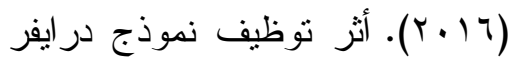

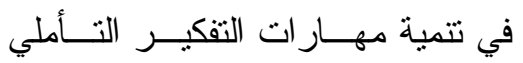
و الاستطلاع العلمي في مادة العلــوم لدى طالبات الصف التاسع الأساسي، رسالة ماجستير، الجامعة الاســلامية،

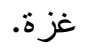

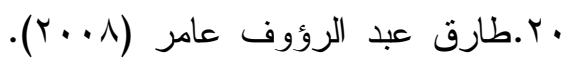
إعداد معلم المستقبل، الجيزة، الـــدار

$$
\text { العالمية للنشر و التوزيع. }
$$

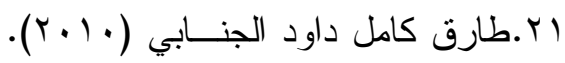

خر ائط المفاهيم و الأسلوب المتمركــز

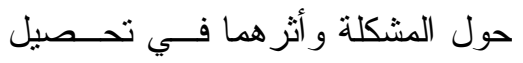

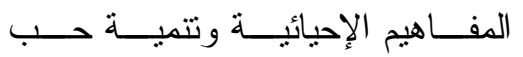
الاستطلاع العلمي، عمان، دار صفاء للنشر و التوزيع r Y..عايش زيتون (911) (الاتجاهـات و الميول العلمية، دار عمان، الأردن.

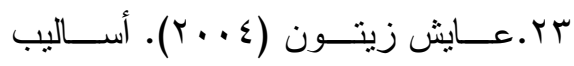
تدريس العلوم، ط (ب)، عمــان، دار الثروق للنشر و التوزيع.

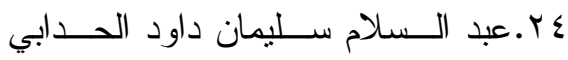
(r.lV) 
لإبية العلمية، المجلد (^) العدد (؟)،

؟ ז.محرم يحيي محمد عفيفـي (10 • (Y).

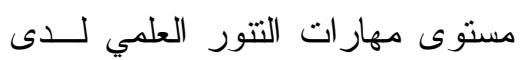

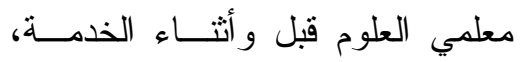
وتأثير نظام الإعداد التكاملي والإعداد

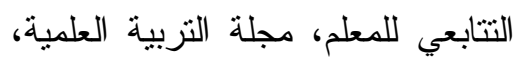

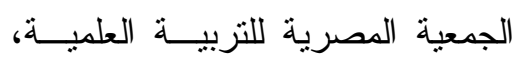

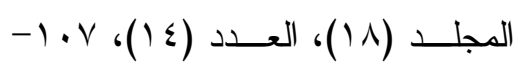
.10.

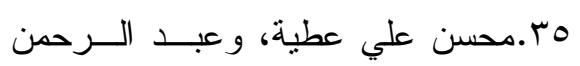

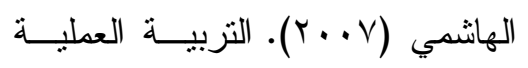
وتطبيقاتها في إعداد معلم المـستقبل،

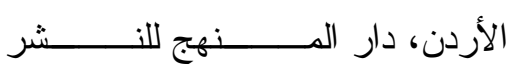

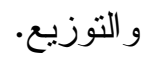

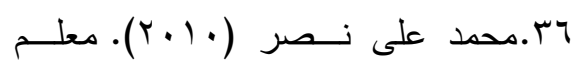
العلوم رؤى المستقبل نحـــو الارتقــــاء

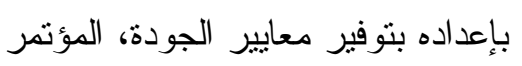

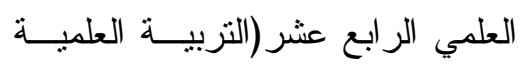

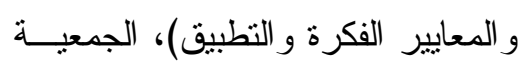

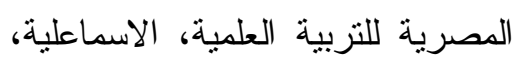

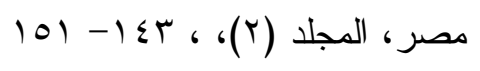
V. محمود رمضان عز ام السيد (Y V (Y). مستوى تمكن معلمي التربية الخاصة

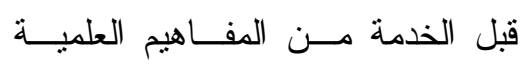
و امتلاكهم لسمات الحس العلمي، مجلة
المعلم، مجلة در اســات عربيــة فــي التزبية و علم النفس، رابطة التربويين

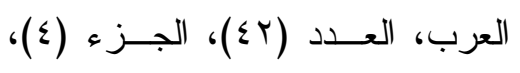
r. O- O.

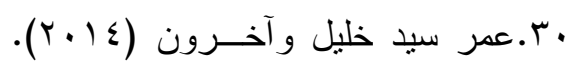
فاعلية برنامج في فلسفة العلم لتتميــة

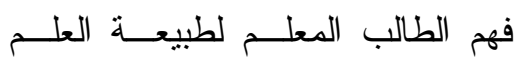
و اكتسابه أخلاقياته، مجلة كلية التزبية،

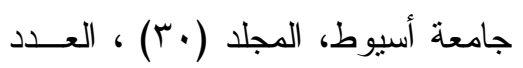
$0) \varepsilon-\operatorname{sTr}$ (1)

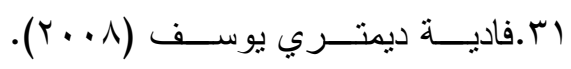

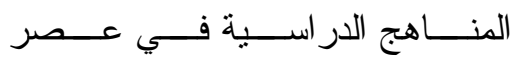
المعلوماتية، المنصورة، عامر للطباعة و النشر

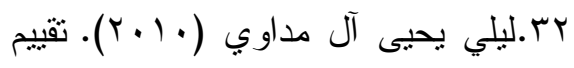
مخرجات برنــامج إعــــاد الطالبـــة المعلمة في قسم الكيمياء بكلية التربية بأبها في ضوء الاتجاهــات الحديثــة، رسالة ماجستير، كلية التزبية، جامعة الملك خالد. بس.ماجدة حبشي محمــد، وهنـــاء عبــــ

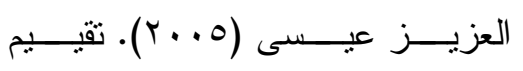

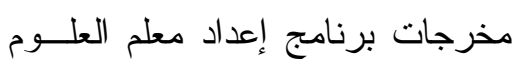

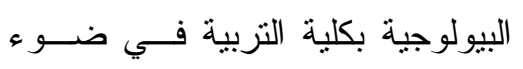
البنية المفاهيمية لعلم البيولوجي، مجلة

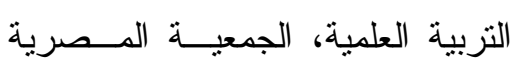


في تتمية المفاهيم الكيميائيــة وحــبـ الاستطلاع العلمي في العلــوم لــدى ولى فئه طالبات الصف الثامن الأساسي بغزة، رسالة ماجستير ، الجامعة الاســلامية، غزة. - ان

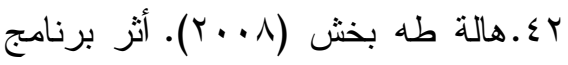
قائم على الوسائط المتعددة في العلــوم على تتمية حب الاستطلاع و الابتكارية

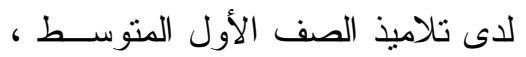

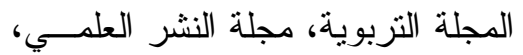
جامعة الكويت، المجلد (YY)، العـدد

r ـ هدى بنــت محمــد حسـين بــابطين

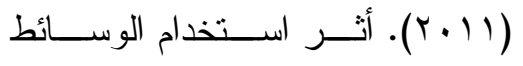

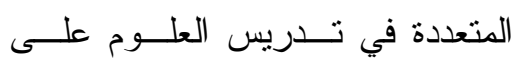
تتمية حـب الاســـطلاع و التحــصيل الدراسي لدى تلميذات الصف الرابــع

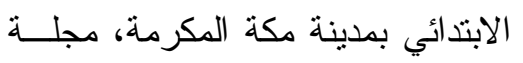

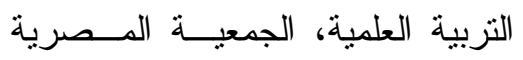

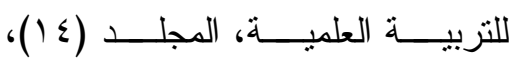
العدد (r).

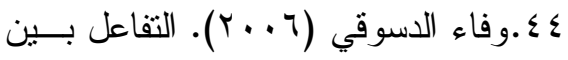
أساليب التحكم التعليمسي ومـستويات حب الاستطلاع وأثزه علــى تتميــة

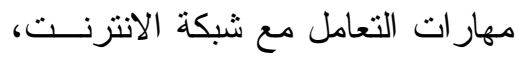

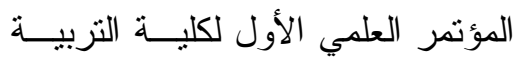

كلية التزبية، جامعة المنصورة، المجلد

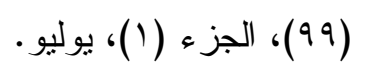

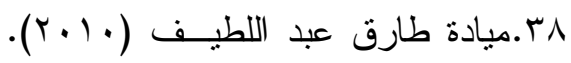

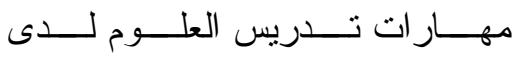

معلمي العلوم في المرحلة الابتدائيــة

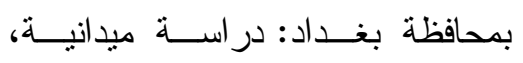

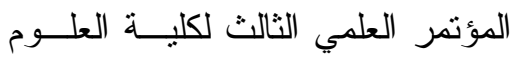

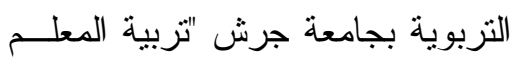

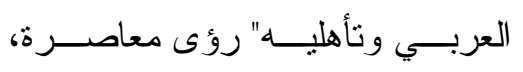

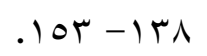

9r.ميادة طارق عبد اللطيـف (1) (ب).

أثز نموذجي Driver و Woods في طي

اكتساب مفــاهيم الــصحة المدرســية فئية

و استبقائها وتتمية حــب الاســنطلاع

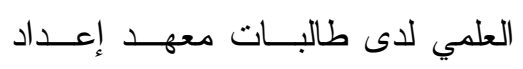

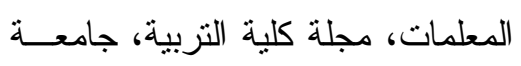

المستتصرية، العـراق، العــد (Y)،

$$
\text { . TrV -000 }
$$

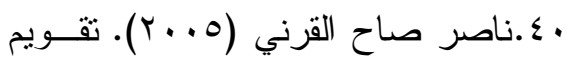

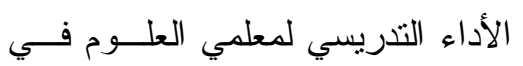

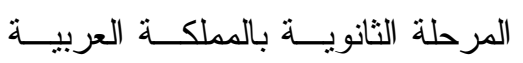

السعودية (من وجهـــة نظــــر الطلبـــة

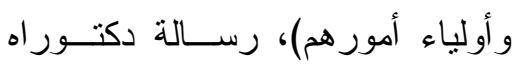

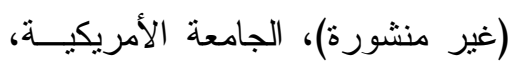

لندن.

اكـناهد محمد الـشوبكى (10 • ب). أتثر

توظيف استز اتيجية التلميذة المعرفيــة اهنة 


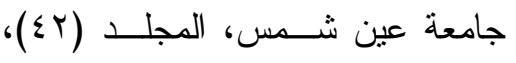

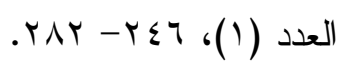

49. Kesner Baruch, Y., SpektorLevy, O.,\& Mashal, N., (2016). Pre-Schoolers Verbal and Behavioral Responses as Indicators of attitudes and Scientific Curiosity, International Journal of Science and Mathematics Education, V.(14), No.(1), 125148

50. Lin Ting, K., Moi Siew, N., (2014). Effects of Outdoor School Ground Lessons on Students' Science Process Skills and Scientific Curiosity, Journal of Education and Learning, V.(3), No. (4), 96107

51. Luera, Gail R., \& Otto, charlotte A., (2005).

Development and Evaluation of an Inquiry- Based Elementary Science Teacher Education Program Reflecting Current Reform Movements. Journal of Science Teacher Education, V.(16), No. (3), 241-258

52. Oberem, Graham E., \& Jasien, Paul G. (2004). Measuring the Effectiveness of an InquiryOriented Summer Physics Course for In-service Teachers. Journal of Physics Teacher Education Online, V.(2), No.(2), 17-23

$$
\begin{aligned}
& \text { النوعية، جامعة المنــصورة جامعسـة } \\
& \text { المنصورة rا- سا ابريل. }
\end{aligned}
$$

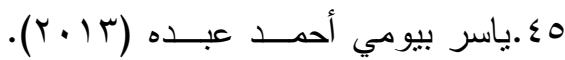

تقويم برنامج إعــداد معلـم العلــوم

بجامعة نجران فـي ضـــو هعـايير

الجودة، در اسات عربية فــي التزبيـــة

و علم النفس، رابطة التربويين العرب،

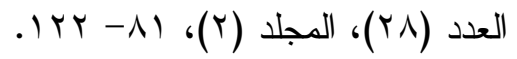

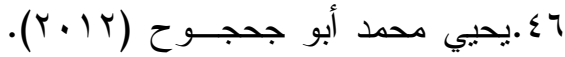

فاعلية دورة التعلم الخماسية في تتمية

المفاهيم العلمية وعمليات العلم وحسب لئب

الاسنطلاع لاى تلاميذ الصف الثـامن

الأساسي بغزة في مادة العلوم، مجلــــة

العلوم التربوية و النفسية، كلية التزبية،

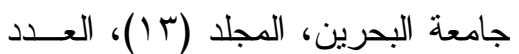
$0 \leq \varepsilon-01 \Gamma \cdot(r)$

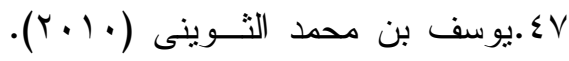

تطوير مؤســسات إعـــاد المعلمــين

بالمملكة العربية السعودية في ضــو

بعض الاتجاهات العالمية المعاصــرة،

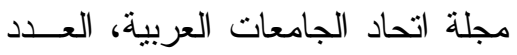

$$
. \Sigma Y V-\Sigma .16(00)
$$

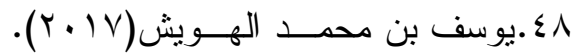

التتمية المهنية لمعلمي المملكة العربية

السعودية في ضوء مهـــار ات القـــرن

الحادي و العشرين، مجلة كلية التزبية

في العلوم التزبوية، كليــة التربيــة، 
53. Ozkan, G., \& Akcay. H., (2016). Preservice Science Teachers' Beliefs about Astronomy Concepts. Universal Journal of Educational Research. V.(4), N. (9), 2092-2099.

54. Vierling, L., \& Jeffrey, G., and George, F. (2006). learning mathematics and earth system science. via satellite, Journal of Geosciences Education, Vol. (54), No. (3) 